\title{
The Relationship Between Firm Productivity, Wage Level and Employees' Age: A Sectoral Perspective
}

\author{
Pål Børing ${ }^{1}$
}

Accepted: 30 June 2021 / Published online: 15 July 2021

(c) The Author(s) 2021

\begin{abstract}
We examine how a firm's productivity level, wage level and productivity-wage gap are related to the age composition of its employees. Panel data of Norwegian firms in the following three sectors are used: the manufacturing sector, the WRT (wholesale and retail trade, repair of motor vehicles and motorcycles) sector, and the PST (professional, scientific and technical activities) sector. Three hypotheses are formulated: a firm's productivity level is negatively affected by its proportion of the oldest workers (H1), a firm's wage level is negatively affected by its proportion of the youngest workers, and positively affected by its proportion of the oldest workers (H2), and a firm's productivity-wage gap is positively affected by its proportion of the youngest workers, and negatively affected by its proportion of the oldest workers (H3). Based on GMM regression in first differences, the estimation results give some support for (a) the hypothesis H1 for the WRT sector, but no support for the manufacturing and PST sectors, (b) H2 for the manufacturing and PST sectors, but little support for the WRT sector, and (c) H3 for the PST sector, but no support for the manufacturing and WRT sectors. The GMM results show that a firm's productivity-wage gap is positively affected by the proportion of the youngest age group in the PST sector, while there is a non-significant effect in the manufacturing and WRT sectors. The proportion of the oldest age group has a non-significant effect on this gap in each of the three sectors. The results indicate that there is no clear evidence of an age-related productivity-wage gap.
\end{abstract}

Keywords Productivity level · Wage level · Productivity-wage gap · Age groups · Matched employer-employee data $\cdot$ Financial data

JEL Classification D21 · D22 · D24 · J24 · J30 $\cdot$ L60 $\cdot$ L80

Pål Børing

paal.boring@nifu.no

1 NIFU Nordic Institute for Studies in Innovation, Research and Education, Økernveien 9, N-0653 Oslo, Norway 


\section{Introduction}

The productivity level is a key determinant of a country's standard of living, and a country's ability to improve its standard of living depends on its ability to increase this level (Krugman, 1997). Employers are trying to increase the productivity of the employees to improve the competitiveness of their firms (Börsch-Supan \& Weiss, 2016). Population ageing represents a challenge in terms of productivity growth, ${ }^{1}$ since employers (and employees) rate the productivity of older workers significantly lower than that of younger workers (Van Dalen et al., 2010). Barthel (2008) emphasises that it is a widespread stereotype that older workers are probably less productive, and that 'the arguments given in the literature are that the physical abilities decrease in general, cognitive abilities at least in some areas' (ibid., p. 3). Solem (2012) concludes that older workers are most likely the last to be dismissed when it comes to downsizing, but they are among the least popular categories to recruit in both rising and falling cycles. ${ }^{2}$ This may be due to a negative gap between productivity and wage among older workers, i.e. they may have a wage that is higher than their productivity (Van Ours, 2009; Van Ours \& Stoeldraijer, 2011). Therefore, it is important to understand how the distribution of employees' age affects the productivity level, the wage level and the productivity-wage gap in firms.

It is difficult to establish the relationship between firm productivity and employees' age (Van Ours, 2009; Van Ours \& Stoeldraijer, 2011). Several studies have examined this relationship, but the results are mixed (see Sect. 3). One reason for the mixed results can be different ways to measure the productivity-age relationship. Another reason can be that there are differences between industrial sectors, since different industries can have different skill compositions of the employees. A third reason can be differences between types of jobs. For example, experience and expertise are beneficial in some jobs, while physical strength and quick reactions are beneficial in others (OECD, 2013). A fourth reason can be that business cycles differ between countries, and between different time periods within a country. Some periods are characterised by rising business cycles, while there have been falling cycles in other periods.

The present study examines how the age composition of a firm's employees is related to its productivity level, wage level and productivity-wage gap. We use panel data of Norwegian firms in different industrial sectors, which covers the period 2000-2016. This period has been characterised by both rising and falling business cycles. As far as we are aware, this is the first study that examines the relationship between employees' age composition and the productivity-wage gap based on data of Norwegian firms. Norway is an interesting case in this context. According to OECD (2020, p. 342), the number of employees as a percentage of the population among the older population (55-64 years) has been relatively high in Norway for the

\footnotetext{
1 Scarth (2002) argues that it is possible that ageing will lead to increases in productivity growth, even if no policy initiative is taken.

${ }^{2}$ Evidence for age discrimination in the hiring process has been found (Carlsson \& Eriksson 2019; Neumark 2020).
} 
last 20 years compared with many other OECD countries. In Norway, this proportion has increased from $65.2 \%$ in 2000 to $72.8 \%$ in 2019 , while for the OECD as a whole (weighted average) there has been an increase from $47.5 \%$ in 2000 to $62.0 \%$ in 2019. The average wage level in 2019 (USD PPPs) was also higher in Norway than in the OECD as a whole (weighted average) (OECD, 2020, p. 364), and the productivity level (measured as the level of GDP per head of population, national currency or current PPPs) in 2019 was much higher in Norway than in the EU as a whole and the OECD as a whole. ${ }^{3}$ In countries such as Norway, with a relatively high average wage level and productivity level, it can be a challenge for the oldest workers to keep up with the individual productivity of younger workers. ${ }^{4}$

To our knowledge, several previous published studies have limited their analyses to the manufacturing sector, and most of the studies referred to in Sect. 3 use data from this sector. Very few studies have estimated the productivity-wage gap based on data that includes a non-manufacturing sector. In contrast to this, we estimate the productivity-wage gap using data of firms in the manufacturing sector, and two service sectors. The following three sectors are included: the manufacturing sector, the sector of wholesale and retail trade, repair of motor vehicles and motorcycles (abbreviated 'the WRT sector'), and the sector of professional, scientific and technical activities (abbreviated 'the PST sector'). These sectors have different skill compositions of the employees, measured by the educational level. This level among the employees is much higher in the PST sector than in the two other sectors, on average. As emphasised above, differences in skill compositions of the employees between industrial sectors may have an impact on how productivity is related to employees' age in different sectors.

In the section on the theoretical framework, explanations for potential effects of age on productivity and wages are given, as well as explanations for a potential agerelated productivity-wage gap. The hypotheses state that a firm's proportion of the oldest workers has a negative effect on its productivity level and productivity-wage gap and a positive effect on its wage level, while a firm's proportion of the youngest workers has a negative effect on its wage level and a positive effect on its productivity-wage gap, where its proportion of the middle-aged workers is used as the reference category.

Descriptive statistics of the panel data show that the productivity level is lowest among the youngest and oldest age groups and highest among the middle-aged group (defined as the 40-49 age group) in each sector (see Sect. 6), where age refers to the average age of employees in each firm. The wage level is lowest among the youngest and oldest age groups and highest among the middle-aged group in the manufacturing and PST sectors, while this level decreases with increasing age group in the WRT sector. The productivity-wage gap is highest among the oldest age group in the manufacturing sector, highest among the youngest and oldest age groups in the PST sector, and increases with increasing age group in the WRT sector.

\footnotetext{
3 Productivity levels (measured as the levels of GDP per hour worked, current prices and current PPPs) in 2017 in several OECD countries are presented in $\operatorname{OECD}(2019$, p. 49).

${ }^{4}$ For a discussion of individual productivity potential, see Børing \& Grøgaard (2021).
} 
These descriptive statistics indicate that the relationships between the productivity level, the wage level, the productivity-wage gap and employees' age may be different when comparing the manufacturing sector with each of the two service sectors, and different when comparing the two service sectors. The question is also whether different skill compositions of the employees may explain possible differences in these relationships after controlling for several other variables.

Based on GMM regression in first differences, the estimation results show that the proportion of the youngest age group has a positive effect on the productivity-wage gap in the PST sector and a non-significant effect in the manufacturing and WRT sectors, while the proportion of the oldest age group has a non-significant effect on this gap in each of the three sectors. These results are to some extent in line with the descriptive statistics for the manufacturing and PST sectors, but to a small extent for the WRT sector. The GMM results give some support for the theoretical expectations formulated in the hypotheses. We also find that the estimated effects of the age groups on the gap are not very sensitive to the inclusion of employee characteristics as gender and educational level, nor are these effects very sensitive to the inclusion of many of the firm characteristics as control variables.

The rest of the article is organised as follows. Section 2 discusses the theoretical framework, and presents the hypotheses that will be tested in the analysis. Previous studies are presented in Sect. 3. In Sect. 4, we describe the data and the variables. The econometric approach is presented in Sect. 5. Descriptive statistics are provided in Sect. 6. The estimation results are presented in Sect. 7. In Sect. 8, we provide some concluding remarks.

\section{The Theoretical Framework and the Hypotheses}

\subsection{Explanations for Potential Effects of Age on Productivity and Wages}

Van Ours \& Stoeldraijer (2011) argue that individual productivity is complex and multidimensional. A number of characteristics that relate to productivity are, inter alia, communication skills, information processing speed, physical strength and endurance, health, self-discipline, flexibility, administrative and strategic capacities, math proficiency, vocabulary size, education, motivation, energy, job experience, cognitive abilities and speediness, quality of worker-job matches, mental elasticity, incentives to invest in training and new competences, and skills obsolescence.

Based on a literature survey, Skirbekk (2004) focuses on age differences in individual productivity and their causes. He concludes that productivity tend to follow an inverted U-shaped profile, where significant decreases take place after the age of 50. Productivity reductions at older ages are particularly strong for work tasks where problem solving, learning and speed are important, while in jobs where experience and verbal abilities matter more, older individuals maintain a relatively high productivity level. Thus, productivity reductions at older ages may be stronger in the PST sector than in the two other sectors, since several indicators of skills use at work are higher in the PST sector compared with the others (OECD, 2016, p. 109). 
Skirbekk (2004) summarises causes of productivity variations over the life cycle. He concludes that cognitive abilities decline from some stage in adulthood, but that targeted training programmes may provide a way of halting age-related decline. Vocabulary size is observed not to differ at older and younger ages, despite a general reduction in other cognitive abilities. Job experience improves productivity for several years, but there comes a point where there is no longer any effect of further experience. On-the-job-training increases productivity up until a point where additional experience no longer provides improvements. Furthermore, physical strength and health fall as employees grow older (Van Ours \& Stoeldraijer, 2011).

In his discussion of the age-earnings profile, Skirbekk (2004) emphasises that there is a strong increase in wage levels until the peak is reached, and that the last years before retirement are characterised by a mild reduction in earnings. He also points out that age-related differences in wages increase with the educational level, and that there is an 'increasing payoff to ability levels within narrowly defined school and occupational groups' (ibid., p. 138). This indicates that the reduction in wages among the oldest workers may be stronger in the PST sector than in the two other sectors due to the decline in cognitive abilities from some stage in adulthood and (due to) the skills used at work.

Furthermore, Skirbekk (2004) concludes that 'the apparent late peak in the ageearnings profile contrasts with the earlier peak in productivity level' (p. 142). This suggests that the wage level will be lower than the productivity level when workers are young. In Sect. 2.2, we provide further explanations for a potential age-related productivity-wage gap (see also Sect. 2.3).

Since we use firm-level data, there is also an issue of aggregation. Van Ours \& Stoeldraijer (2011) claim that 'if individuals are aggregated to the firm level, the relationship between productivity and age should still hold' (p. 115). Therefore, the hypotheses in Sect. 2.3 concerning how age is related to the productivity level and the wage level are based on the literature survey on individual productivity in Skirbekk (2004).

\subsection{Explanations for a Potential Age-Related Productivity-Wage Gap}

The analysis in Lazear (1979) constitutes the main theoretical framework on how the productivity-wage gap is related to employees' age. In his study, a theoretical explanation is given for the existence of mandatory retirement. The theory states that it pays both workers and firms to agree to a long-term wage stream which pays workers less than their value of marginal product (VMP) when young and more than their VMP when old. By using this payment schedule, the worker's lifetime VMP is higher than it would be in the absence of that scheme because this provides valuable incentives to the worker, which would otherwise be lost to moral hazard. According to Lazear (1979), mandatory retirement is a necessary consequence of this payment schedule, and the most important implication of this theory is that both workers and firms benefit from the existence of mandatory retirement.

There are other explanations for a potential age-related productivity-wage gap. Henkens \& van Dalen (2013) claim that unions pay more attention to the preferences 
of older workers than younger workers, and they refer to this as 'the unions' distributional preferences'. The reason is that older workers are more likely to be members of a union than younger workers, because the older need more union protection in case of, for example, threatening discharge (van den Berg \& Groot, 1992).

The unions' distributional preferences can explain various union practices, including rising seniority-wage profiles (de Hek \& van Vuuren, 2011). For example, Tracy (1986) explains the presence of seniority-based wage increases. He demonstrates that if the union can be committed to a long-term contract by the union organisers, then the organisers will structure the contract so that wages increase with seniority. Seniority-based wage increases act as a substitute for initiation fees, and thus serve as one means of appropriating rents from future members of the union.

In another study, Loewenstein \& Sicherman (1991) argue that many workers prefer increasing wage profiles over flatter or decreasing wage profiles of greater monetary value. They find that a majority of the respondents in their survey rank increasing payments higher than decreasing payments.

\subsection{The Hypotheses}

Skirbekk (2004) concludes that productivity decreases after the age of 50 (see Sect. 2.1), where 'an important cause of these age-related productivity declines is likely to be age-specific reductions in cognitive abilities' (p. 143). Since we use proportions of employees in different age groups when age is modelled, the following hypothesis is formulated:

H1: A firm's productivity level is negatively affected by its proportion of the oldest workers, where its proportion of the middle-aged workers is used as the reference category.

According to Skirbekk (2004), the age-earnings profile is characterised by a relatively strong increase in wage levels until the peak is reached, and with a mild reduction in earnings the last years before retirement. He also concludes that earnings tend to increase until relatively late in the working life. Therefore, we formulate the following hypothesis:

H2: A firm's wage level is negatively affected by its proportion of the youngest workers, and positively affected by its proportion of the oldest workers, where its proportion of the middle-aged workers is used as the reference category.

The theory of Lazear states that it is preferable for both workers and firms that the wage is lower than the VMP ('underpaid') when workers are young, and higher than the VMP ('overpaid') when they are old (see Sect. 2.2). We therefore expect that there is a positive productivity-wage gap among the youngest workers, and a negative gap among the oldest workers. Thus, the following hypothesis is formulated:

H3: A firm's productivity-wage gap is positively affected by its proportion of the youngest workers, and negatively affected by its proportion of the oldest workers, where its proportion of the middle-aged workers is used as the reference category.

The hypotheses H1-H3 will be tested in Sect. 7.1. 


\section{Previous Studies}

Many studies focus on the relationship between productivity and employees' age, and some of these studies also examine how wage is related to age. Several of the studies are based on matched employer-employee data for a single country (Aubert \& Crépon, 2006; Börsch-Supan \& Weiss, 2016; Cataldi et al., 2012; Dostie, 2011; Göbel \& Zwick, 2012; Hellerstein \& Neumark 2007, Lallemand \& Rycx, 2009; Van Ours, 2009; Van Ours \& Stoeldraijer, 2011). In this section, we provide a more detailed description of the employer-employee studies, as well as some other previous studies.

A literature survey is presented in Skirbekk (2004) on how individual productivity varies with age. An overview over how employer-employee studies relate to age is presented in his article, where the employer-employee data sets cover both manufacturing and non-manufacturing sectors. For most of these studies, productivity is found to be concave in age. 'Individuals in their $30 \mathrm{~s}$ and $40 \mathrm{~s}$ have the highest productivity levels. Employees above the age of 50 are found to have a lower productivity than younger individuals, in spite of their higher wage levels' (p. 140).

In another study, Skirbekk (2008) estimates the relation between age and productivity potential. He finds that productivity peaks for the 35-44 age group, but that the productivity peak shifts toward younger ages if the demand for experience falls. It is also emphasised in his study that age-productivity profiles, where productivity drops from mid-working life, can contrast with a late peak in the age-earnings curve.

Aubert \& Crépon (2006) use matched employer-employee data covering firms in the manufacturing, trading and services sectors in France. They find that productivity increases with age until age 40 and then remains stable after this age. The estimated age-productivity and age-labour cost profiles are found similar in all sectors up to age 55, and the evidence for a significant productivity-labour cost gap after age 55 is quite weak.

The analysis in Hellerstein \& Neumark (2007) is based on matched employer-employee data for the U.S. Their study focuses on the manufacturing sector. They conclude that both the estimated productivity profile and the estimated wage profile are concave in age, but their results imply that the wage profile is steeper than the productivity profile. Using matched employer-employee data of Belgian firms in the private sector, which cover both manufacturing and non-manufacturing firms, Lallemand \& Rycx (2009) find that young workers are significantly more productive than older workers.

Van Ours (2009) analyses the relationship between age and productivity based on Dutch data on individuals and firms. When analysing individual-level data on running, he finds evidence of a productivity decline after age 40 . He also uses individual-level data on publishing in economics journals, but finds no evidence of a productivity decline, even after age 50 . Then he examines the potential agerelated productivity-wage gap using matched worker-firm data from manufacturing, but concludes that there is little evidence of an increasing productivity-pay gap at higher ages. 
Dostie (2011) uses Canadian linked employer-employee data to estimate agebased wage and productivity differentials. He concludes that wages do not deviate significantly from productivity, on average. However, productivity appears to be lower than wages for older workers with at least an undergraduate degree, while the reverse seems true for younger men.

Using matched worker-firm data from Dutch manufacturing, Van Ours \& Stoeldraijer (2011) find that productivity of workers will go down eventually at higher age, but it is not clear where the turning point of the age-productivity profile is located. They conclude that there is no evidence of an age-related productivity-pay gap. Based on German linked employer-employee data, the results in Göbel \& Zwick (2012) suggest that there are no pure age effects on productivity in the manufacturing, metal manufacturing and services sectors.

Cataldi et al. (2012) evaluate the relationship between workforce age, wage and productivity at the firm level based on Belgian data on private sector workers and firms, which include both the manufacturing sector and non-manufacturing sectors. The results in their study suggest that older workers are significantly less productive than prime age and young workers, while they do not find any significant differences in the productivity between middle-aged and young workers. Their findings also indicate that average hourly wages within firms increase significantly with workers' age. Therefore, they conclude that young workers appear to be paid below their marginal productivity, while older workers appear to be 'overpaid'.

The study by Börsch-Supan \& Weiss (2016) examines the relation between workers' age and their productivity in an assembly plant of a truck manufacturer located in Germany. Their findings show that the average age-productivity profile of individual workers is increasing until age 65 . They conclude that they "cannot confirm the wide-spread opinion that older workers are less productive than younger workers' (p. 37).

Bryson et al. (2020) examine the relationship between the age composition of the workforce and workplace performance using panel data for private-sector workplaces in Britain. They find some evidence that a higher proportion of older or younger employees result in a reduction in workplace labour productivity. Their results suggest that there is a 'productivity penalty' from hiring older workers, but that hiring very young workers impairs productivity to an even greater extent.

To our knowledge, few studies with focus on the age-productivity relationship are based on data for several countries. One exception is Aiyar et al. (2016). Based on data covering up to 24 countries, they examine the relationship between workforce ageing and productivity in Europe. They estimate that a 1 percentage point increase in the 55-64 age cohort of the labour force is associated with a reduction in total factor productivity of about $4 / 5$ of a percentage point.

Based on the studies above, it is not possible to draw any unambiguous conclusions about how productivity is related to age. The results in several of these studies suggest that older workers are less productive than younger workers (Lallemand \& Rycx, 2009; Van Ours, 2009 when using data on running, Van Ours \& Stoeldraijer, 2011; Cataldi et al., 2012), while this is hardly supported by some of the other studies (Aubert \& Crépon 2006, Van Ours, 2009 when using data on publishing in economics journals, Göbel \& Zwick, 2012; Börsch-Supan \& Weiss, 2016). 
The results in one of the studies (Cataldi et al., 2012) indicate that young workers are paid below their marginal productivity ('underpaid'), while older workers are 'overpaid'. Three of the other studies find that there is no evidence of an age-related productivity-pay gap (Van Ours \& Stoeldraijer, 2011), little evidence of an increasing productivity-pay gap at higher ages (Van Ours, 2009), and that the evidence for a significant productivity-labour cost gap at higher ages is quite weak (Aubert \& Crépon 2006).

In a recent study by Töpfer (2020), the difference in pay between elderly (55-64) and adult (34-54) workers along the wage distribution is examined using Italian microdata. Unlike Cataldi et al. (2012), Töpfer (2020) finds no evidence of (substantial) overpayment of elder and underpayment of adult workers once one accounts for generally unobserved labour market.

\section{The Data}

We use a panel data set of Norwegian firms for the period 2000-2016, which comprises annual administrative files from Statistics Norway. The data set is based on matched employer-employee register data and financial register data. The employer-employee data contains yearly information on all employees, and all plants and enterprises, in Norway. In the employer-employee data, both plants and enterprises are identified by unique codes. There is a corresponding unique enterprise code to each plant's unique code, where an enterprise consists of at least one plant.

The financial register data contains yearly information on total assets and compensation of employees for all enterprises in Norway. For each year, the capital stock is equal to total assets, and the wage costs are equal to compensation of employees. Total assets are the sum of current and fixed assets. Compensation of employees is wages and salaries plus employers' social contributions. Both total assets and compensation of employees are measured in 1000 NOK.

Firms are identified at the enterprise level in the financial data, where enterprises are identified by unique codes. These enterprise codes correspond to the enterprise codes in the employer-employee data. The employer-employee data can therefore be linked to the financial data at the enterprise level based on the enterprise codes.

In the analysis, firms are defined at the plant level. One reason for this is to account for potential firm heterogeneity at this level. Another reason is that a firm's capital stock and wage costs are the only variables that are defined at the enterprise level, while all other variables are defined at the plant level. We link the financial register data to the matched employer-employee register data at the enterprise level based on the enterprise codes. This implies that firms within the same enterprise will have the same (monetary values of the) capital stock and wage costs.

\subsection{The Final Sample of Firms}

For many observations in the combined matched employer-employee and financial register data, firms are registered with non-positive turnover, non-positive capital stock, or non-positive wage costs. Since the log of the turnover per 
employee, the log of the capital stock per employee and the log of the wage costs per employee are used as variables in the regressions, the sample of firms only includes observations in main industrial sectors where relatively few firms are registered with non-positive turnover, non-positive capital stock, or non-positive wage costs. If we only include main industries where at least $90 \%$ of the observations concern firms that are registered with positive turnover, and $70 \%$ of the observations concern firms that are registered with positive capital stock and wage costs, the following four industries satisfy these requirements (alphabetical NACE code in parenthesis, SIC2007): manufacturing (C), wholesale and retail trade, repair of motor vehicles and motorcycles $(\mathrm{G})$, information and communication $(\mathrm{J})$, and professional, scientific and technical activities (M).

We will basically only include firms in the sample that are registered in one of the four main industrial sectors $\mathrm{C}, \mathrm{G}, \mathrm{J}$ and $\mathrm{M}$. However, since we use panel data, a firm's industrial sector affiliation can vary between different years in the period 2000-2016. Therefore, we basically include all firms in the sample that are registered as firms in one of these four industries for at least one of the years in 2000-2016. This reduces the number of observations in the combined data from $4,718,916$ to $1,347,743$.

When using two-step GMM regression in first differences (with the same options as described in Sect. 5.4) for the sample of firms that are registered in the main industrial sector $J$ for at least one of the years in 2000-2016, the overidentification test of all instruments (Sargan statistic, $p$ value) reports that 'equation exactly identified'. This is reported when using each of the three dependent variables (see Sect. 4.2) with the same explanatory variables as in Tables 2, 3, 4, and when using each of the three dependent variables with the key regressors as the only explanatory variables. As a consequence of this, we exclude firms that are registered in the $J$ sector (for at least one of the years in 2000-2016) from the final sample. The number of observations in the combined data is thus reduced to $1,257,045$.

The final sample thus consists of firms that are registered in one of the three main industrial sectors C, G and M for at least one of the years in 2000-2016. There are 149,837 unique firms in the final sample. Based on this (final) sample, we create three sectors:

The manufacturing sector: All firms in the final sample that are registered in the main industrial sector $\mathrm{C}$ for at least one of the years in 2000-2016. The manufacturing sector consists of 219,630 observations. For $88 \%$ of these observations, a firm is registered in the main industrial sector $\mathrm{C}$. There are 23,350 unique firms in the manufacturing sector.

The WRT sector: All firms in the final sample that are registered in the main industrial sector $\mathrm{G}$ for at least one of the years in 2000-2016. The WRT sector consists of 780,498 observations. For $94 \%$ of these observations, a firm is registered in the main industrial sector $\mathrm{G}$. There are 88,815 unique firms in the WRT sector.

The PST sector: All firms in the final sample that are registered in the main industrial sector M for at least one of the years in 2000-2016. The PST sector consists of 293,311 observations. For $90 \%$ of these observations, a firm is registered in the main industrial sector M. There are 40,697 unique firms in the PST sector. 
Due to how the final sample is created, the manufacturing, WRT and PST sectors are not mutually exclusive. We find that $2 \%$ of the total observations in the final sample are included in both the manufacturing and WRT sectors, $0.5 \%$ of the total observations are included in both the manufacturing and PST sectors, while $1 \%$ of the total observations are included in both the WRT and PST sectors.

\subsection{The Dependent Variables}

The following three level variables are used as dependent variables when the estimation is based on the OLS or FE regression technique (see Sect. 5.4): the productivity level, the wage level, and the productivity-wage gap. When using the GMM regression, the dependent variables are the first differences of these three level variables. The productivity level is measured by the log of the turnover per employee, the wage level is measured by the log of the wage costs per employee, and the productivity-wage gap is measured by the difference between the log of the turnover per employee and the log of the wage costs per employee. This means that the gap is equal to the log of the fraction between the turnover and the wage costs. Turnover per employee can be considered as a measure of (average) labour productivity. All dependent variables are continuous.

Turnover is the sum of payment of sales to customers, sales of goods for resale, and gross income from other business activity. Turnover includes income from rent and commission income, but not government subsidies or profit from the disposal of fixed assets. Value added tax is not included in the turnover either. Turnover is given in $1000 \mathrm{NOK}$.

\subsection{The Explanatory Variables}

The explanatory level variables used in the OLS and FE regressions are: the log of the number of employees in each firm, proportions of employees in different age groups, the proportion of females of total employees, the proportion of employees with unknown gender, proportions of employees at different highest attained educational levels, industrial sectors, a firm's geographical location according to county, and the year(s) a firm is registered. When the productivity level and the productivity-wage gap are used as dependent variables, the log of the capital stock per employee is also used as an explanatory level variable. In the GMM regression, the explanatory variables are the first differences of the explanatory level variables. The proportions of employees in different age groups (in levels or first differences) are the key regressors, while the other explanatory variables are the control variables. Industrial sectors (which include 80 dummies), location (22 dummies) and years of registration (17 dummies) are represented by dummy variables, while the other explanatory variables are continuous.

An employee's age is based on his or her year of birth. In the combined data, we do not have information about a person's exact year of birth, only that the person is born in one of a series of three-year intervals: 2002-2004, 1999-2001, 1996-1998, etc. A person's age is calculated by using the middle year in each interval. 
When modelling employees' age, proportions of employees in different age groups are used. The different age groups are: under 30 years, 30-39 years, 40-49 years, 50-59 years, 60 years or older, and those with unknown age. The proportion of employees in the 40-49 age group is used as the reference category. We have also tested using the following two continuous variables as key regressors: the average age of employees, and this age variable squared. These continuous age variables will not be used as key regressors in the analysis due to the multicollinearity problem of using both variables.

Educational level is based on the Norwegian Standard Classification of Education (NUS2000). We differentiate between the following highest attained educational levels: employees with lower secondary education or less, upper secondary education (the reference category), higher education, and those with unknown or no completed education.

The classification of industrial sectors is based on the Standard Industrial Classification (SIC2007), two-digit NACE code level. The following industrial groups are used as the reference categories: manufacture of food products (NACE code 10) for the manufacturing sector, retail trade, except of motor vehicles and motorcycles (NACE code 47) for the WRT sector, and architectural and engineering activities, technical testing and analysis (NACE code 71) for the PST sector. The reference category is 2008 for the year dummies.

\section{The Econometric Approach}

\subsection{The Productivity Equation}

The productivity equation is based on the productivity models used in Børing (2014). A firm's production can be described by the following Cobb-Douglas production function:

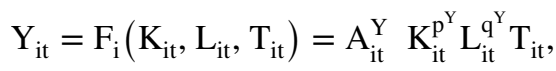

where $\mathrm{Y}_{\mathrm{it}}$ is the monetary value of the production, $\mathrm{K}_{\mathrm{it}}$ is the monetary value of the capital stock, $\mathrm{L}_{\mathrm{it}}$ is the number of employees, and $\mathrm{T}_{\mathrm{it}}$ is the state of technology, in firm $\mathrm{i}$ in yeart, $=\mathrm{i} 1,2, \ldots, \mathrm{n} . \mathrm{A}_{\mathrm{it}}^{\mathrm{Y}}$ represents the Hicksian neutral efficiency level, which is not observable. The function in (1) has non-constant returns to scale in $\left(\mathrm{K}_{\mathrm{it}}, \mathrm{L}_{\mathrm{it}}\right)$ if the sum of the parameters, $\mathrm{d}^{\mathrm{Y}}=\mathrm{p}^{\mathrm{Y}}+\mathrm{q}^{\mathrm{Y}}$, is not equal to 1 . The production function can be rewritten in terms of labour productivity, $\mathrm{Y}_{\mathrm{it}} / \mathrm{L}_{\mathrm{it}}$, as

$$
\frac{Y_{i t}}{L_{i t}}=A_{i t}^{Y}\left(\frac{K_{i t}}{L_{i t}}\right)^{p^{Y}} L_{i t}^{d^{Y}-1} T_{i t}
$$

chnology $\mathrm{T}_{\mathrm{it}}$ is modelled in the following way:

$$
\mathrm{T}_{\mathrm{it}}=\exp \left(\mathrm{X}_{\mathrm{it}} \mathrm{b}^{\mathrm{Y}}+\mathrm{Z}_{\mathrm{it}} \mathrm{c}^{\mathrm{Y}}\right)
$$


Here $\mathrm{X}_{\mathrm{it}}$ is a row vector of the key regressors, $\mathrm{Z}_{\mathrm{it}}$ is a row vector of explanatory variables other than $\left(\ln \left(\mathrm{K}_{\mathrm{it}} / \mathrm{L}_{\mathrm{it}}\right), \ln \mathrm{L}_{\mathrm{it}}\right)$ and the key regressors, and $\left(\mathrm{b}^{\mathrm{Y}}, \mathrm{c}^{\mathrm{Y}}\right)$ are column vectors of coefficients. One of the elements in $\mathrm{Z}_{\text {it }}$ is one.

If we take the logarithm in (2), and use (3), we get that

$$
\ln \left(\frac{Y_{i t}}{L_{i t}}\right)=a^{Y}+p^{Y} \ln \left(\frac{K_{i t}}{L_{i t}}\right)+\left(d^{Y}-1\right) \ln L_{i t}+X_{i t} b^{Y}+Z_{i t} c^{Y}+\varepsilon_{i t}^{Y},
$$

where $\ln \mathrm{A}_{\mathrm{it}}=\mathrm{a}^{\mathrm{Y}}+\varepsilon_{\mathrm{it}}^{\mathrm{Y}} \cdot \mathrm{a}^{\mathrm{Y}}$ measures the mean efficiency level across firms and over time, and $\varepsilon_{i t}^{Y}$ is the time- and firm-specific deviation from this mean. (4) is used when estimating how a firm's productivity level is affected by the explanatory variables $\left(\ln \left(\mathrm{K}_{\mathrm{it}} / \mathrm{L}_{\mathrm{it}}\right), \operatorname{lnL} \mathrm{L}_{\mathrm{it}}, \mathrm{X}_{\mathrm{it}}, \mathrm{Z}_{\mathrm{it}}\right)$. This type of estimation is based on the OLS or FE regression technique.

Changes in the productivity level may affect changes in the age composition of the employees in a firm. The reason is that a firm with aiming to increase its productivity level may choose to change the age composition. Thus, there is a potential endogeneity problem associated with the key regressors. The problem is to find exogenous instruments. This means that the instruments should not be affected by the productivity level, but correlated with the endogenous variables. When using the GMM regression technique, we estimate the productivity and wage equations and the equation of the productivity-wage gap in first differences, with the following options: the first differences of the key regressors, $\Delta X_{i t}=X_{i t}-X_{i, t-1}$, are listed as the endogenous regressors, and $\Delta X_{i t}-\Delta X_{i, t-1}$ are used as the excluded instruments. The underlying assumption is that changes in the productivity level between $\mathrm{t}-1$ and $\mathrm{t}$ are uncorrelated with the difference between $\Delta X_{\text {it }}$ (the differences in the key regressors between $t-1$ and $t$ ) and $\Delta \mathrm{X}_{\mathrm{i}, \mathrm{t}-1}$ (the differences in the key regressors between $\mathrm{t}-2$ and $\mathrm{t}-1$ ). The productivity equation is derived by taking first differences of (4):

$$
\Delta \ln \left(\frac{\mathrm{Y}_{\mathrm{it}}}{\mathrm{L}_{\mathrm{it}}}\right)=\mathrm{p}^{Y} \Delta \ln \left(\frac{\mathrm{K}_{\mathrm{it}}}{\mathrm{L}_{\mathrm{it}}}\right)+\left(\mathrm{d}^{Y}-1\right) \Delta \ln \mathrm{L}_{i t}+\Delta X_{i t} b^{Y}+\Delta Z_{i t} c^{Y}+\Delta \varepsilon_{i t}^{Y}
$$

Alternatively, we could instead assume that changes in productivity betwn $t-1$. and $t$ are uncorrelated with $X_{i, t-s}(s \geq 2)$, i.e. the levels of the key regressors in $\mathrm{t}-2$ or earlier. To the extent that there is a relatively strong correlation between values of each of the key regressors (or at least some of them) at different times, changes in the productivity level may be relatively weaker correlated with the difference between $\Delta \mathrm{X}_{\mathrm{it}}$ and $\Delta \mathrm{X}_{\mathrm{i}, \mathrm{t}-1}$ than with $\mathrm{X}_{\mathrm{i}, \mathrm{t}-\mathrm{s}}$. For example, if we assume that there is a linear relationship between one of the key regressors $\mathrm{X}_{\mathrm{i}, \mathrm{t}-1}$ and $\mathrm{X}_{\mathrm{i}, \mathrm{t}-2}$ with an error term $\mathrm{u}_{\mathrm{i}, \mathrm{t}-1}$ included, $X_{i, t-1}=\delta X_{i, t-2}+\mu+u_{i, t-1}$, then $\Delta X_{i t}=\delta^{s-1}(\delta-1) X_{i, t-s}+\delta^{s-1} \mu+u_{i t}+\sum_{\tau=1}^{s-1} \delta^{\tau-1}(\delta-1) u_{i, t-\tau}$, where $\delta$ and $\mu$ are 
coefficients. ${ }^{5}$ This implies that $\Delta \mathrm{X}_{\mathrm{it}}$ is linear related to $\mathrm{X}_{\mathrm{i}, \mathrm{t}-\mathrm{s}}$ (included the composite error term $\left.\mathrm{u}_{\mathrm{it}}+\sum_{\tau=1}^{\mathrm{s}-1} \delta^{\tau-1}(\delta-1) \mathrm{u}_{i, t-\tau}\right)$. In the case of a linear relationship between $\mathrm{X}_{\mathrm{i}, \mathrm{t}-1}$ and $\mathrm{X}_{\mathrm{i}, \mathrm{t}-2}$, we prefer to use $\Delta \mathrm{X}_{\mathrm{it}}-\Delta \mathrm{X}_{\mathrm{i}, \mathrm{t}-1}$ as the excluded instruments, and not $\mathrm{X}_{\mathrm{i}, \mathrm{t}-\mathrm{s}}$.

\subsection{The Wage Equation}

Based on the modelling strategy in Van Ours (2009, Sect. 4.3), we assume that a firm's wage level, i.e. its wage costs per employee, is a function of $\left(\operatorname{lnL} L_{i t}, X_{i t}, Z_{i t}\right)$, but not a function of $\ln \left(\mathrm{K}_{\mathrm{it}} / \mathrm{L}_{\mathrm{it}}\right)$. The wage level is modelled as follows:

$$
\ln \left(\frac{W_{i t}}{L_{i t}}\right)=a^{W}+d^{W} \ln L_{i t}+X_{i t} b^{W}+Z_{i t} c^{W}+\varepsilon_{i t}^{W}
$$

Here $\mathrm{W}_{\mathrm{it}}$ is the wage costs, $\mathrm{W}_{\mathrm{it}} / \mathrm{L}_{\mathrm{it}}$ is the wage level, $\varepsilon_{i t}^{W}$ is an error term, $\left(\mathrm{a}^{\mathrm{W}}, \mathrm{d}^{\mathrm{W}}\right)$ are coefficients, and $\left(\mathrm{b}^{\mathrm{W}}, \mathrm{c}^{\mathrm{W}}\right)$ are column vectors of coefficients. (6) is used in the OLS and FE regressions when estimating how a firm's wage level is affected by the explanatory variables. In the GMM regression, we estimate (6) in first differences:

$$
\ln \left(\frac{W_{i t}}{L_{i t}}\right)=a^{W}+d^{W} \ln L_{i t}+X_{i t} b^{W}+Z_{i t} c^{W}+\varepsilon_{i t}^{W}
$$

\subsection{The Equation of the Productivity-Wage Gap}

The equation of the productivity-wage gap can be derived directly by taking the difference between (4) and (6) (see Sect. 6.2 in Van Ours \& Stoeldraijer, 2011):

$$
G_{i t}=\ln \left(\frac{Y_{i t}}{L_{i t}}\right)-\ln \left(\frac{W_{i t}}{L_{i t}}\right)=a+p \ln \left(\frac{K_{i t}}{L_{i t}}\right)+d \ln L_{i t}+X_{i t} b+Z_{i t} c+\varepsilon_{i t},
$$

where $\mathrm{G}_{\mathrm{it}}$ is the productivity-wage gap, and $\varepsilon_{i t}=\varepsilon_{i t}^{Y}-\varepsilon_{i t}^{W}$ is an error term. Here we define the following scalar coefficients and column vectors of coefficients: $\mathrm{a}=\mathrm{a}^{\mathrm{Y}}-\mathrm{a}^{\mathrm{W}}, \mathrm{p}=\mathrm{p}^{\mathrm{Y}}, \mathrm{d}=\mathrm{d}^{\mathrm{Y}}-\mathrm{d}^{\mathrm{W}}-1, \mathrm{~b}=\mathrm{b}^{\mathrm{Y}}-\mathrm{b}^{\mathrm{W}}$, and $\mathrm{c}=\mathrm{c}^{\mathrm{Y}}-\mathrm{c}^{\mathrm{W}}$. (8) is used in the OLS and FE regressions when estimating how a firm's productivity-wage gap is affected by the explanatory variables. When using the GMM regression, we estimate (8) in first differences:

$$
\Delta G_{i t}=\Delta \ln \left(\frac{Y_{i t}}{L_{i t}}\right)-\Delta \ln \left(\frac{W_{i t}}{L_{i t}}\right)=p \Delta \ln \left(\frac{K_{i t}}{L_{i t}}\right)+d \Delta \ln L_{i t}+\Delta X_{i t} b+\Delta Z_{i t} c+\Delta \varepsilon_{i t}
$$

\footnotetext{
5 This relationship can be shown by induction. If $\mathrm{s}=2$, then $\Delta X_{i t}=d(d-1) X_{i, t-2}+d \mu+\mu_{i t}+(d-1) u_{i, t-1}$, which is correct. If it is correct for $\mathrm{s}=\varphi$, then $\Delta \mathrm{X}_{\mathrm{it}}=\mathrm{d}^{\mathrm{f}}(\mathrm{d}-1) \mathrm{X}_{\mathrm{i}, \mathrm{t}-(\mathrm{f}+1)}+\mathrm{d}^{\mathrm{f}} \mu+\mathrm{u}_{\mathrm{it}}+\sum_{\mathrm{t}=1}^{\mathrm{f}} \mathrm{d}^{\mathrm{t}-1}(\mathrm{~d}-1) u_{\mathrm{i}, \mathrm{t}-\mathrm{t}}$. Thus, the relationship is also correct for $\mathrm{s}=\varphi+1$. It follows that it is shown by induction.
} 


\subsection{The Regression Techniques}

Three regression techniques are used in the analysis: OLS, fixed-effects (FE) regression, and two-step efficient generalized method of moments (GMM) regression. In the same way as in, for example, Cardoso et al. (2011) and Van Ours \& Stoeldraijer (2011), we estimate the productivity and wage equations and the equation of the productivity-wage gap in first differences when using the two-step GMM regression technique. We take first differences of all level variables used as dependent and explanatory variables. The first difference of a dummy variable takes the values -1 , 0 and 1.

When the estimation is based on the two-step GMM regression, we use the 'ivreg2' command in Stata with the following specified options: Two-step GMM estimator (the 'gmm2s' option), the first differences of the explanatory level variables except the first differences of the key regressors $\left(\Delta \ln \left(\mathrm{K}_{\mathrm{it}} / \mathrm{L}_{\mathrm{it}}\right), \Delta \ln \mathrm{L}_{\mathrm{it}}, \Delta \mathrm{Z}_{\mathrm{it}}\right)$ are the exogenous regressors or 'included instruments', $\Delta X_{i t}$ are the endogenous regressors that are being 'instrumented', the difference between $\Delta \mathrm{X}_{\mathrm{it}}$ and $\Delta \mathrm{X}_{\mathrm{i}, \mathrm{t}-1}$ are the exogenous variables excluded from the regression or 'excluded instruments', $\Delta X_{i t}$ are the endogenous regressors (the 'endog' option), requesting the first-stage diagnostic and identification statistics (the 'ffirst' option), and kernel-based autocorrelation-consistent (AC) and heteroskedastic and autocorrelation consistent (HAC) standard errors and covariance estimation (the 'bw(1)' option).

\section{Descriptive Statistics}

In Table 1, we present descriptive statistics for the full sample and the different subsamples (S1-S6) by type of sector. The column 'full sample' shows statistics using all observations in each sector. Each of the columns S1-S6 shows statistics using the number of observations for a given combination of dependent variable and regression technique (see Notes 1-6 in the table). With the exception of the number of employees in each firm, there are small differences in the mean values of firm and employee characteristics if we compare the different subsamples with the full sample in each sector. We see that there is a higher proportion of firms with 1-9 employees, and a lower proportion of firms with 10-24 employees, in the full sample than in the subsamples in each sector. The differences in the proportion of firms with 1-9 employees are larger among manufacturing firms than among firms in each of the two other sectors. There is also a relatively lower proportion of firms with 25-99 employees in the full sample in the manufacturing sector. As a consequence of this, the average number of employees in each firm is relatively lower in the full sample in the manufacturing sector, while there are small differences in the two service sectors. This means that small firms are overrepresented in the full sample compared with the subsamples. In Sect. 7.1, we have conducted a sensitively analysis for each sector in order to examine whether the estimated effects of the proportions of the different age groups are sensitive to this overrepresentation.

The rest of this section is based on the descriptive statistics for the different subsamples in Table 1 . We see that the proportion of observations concerning 
Table 1 Mean values of firm and employee characteristics for the full sample and the different subsamples (S1-S6) by type of sector

\begin{tabular}{|c|c|c|c|c|c|c|c|}
\hline & S1 & S2 & S3 & S4 & S5 & S6 & Full sample \\
\hline \multicolumn{8}{|l|}{ The manufacturing sector } \\
\hline $\begin{array}{l}\text { Proportion of females of total } \\
\text { employees }\end{array}$ & $23 \%$ & $23 \%$ & $23 \%$ & $23 \%$ & $23 \%$ & $23 \%$ & $24 \%$ \\
\hline \multicolumn{8}{|l|}{ Proportion of employees by age } \\
\hline Under 30 years & $17 \%$ & $17 \%$ & $17 \%$ & $17 \%$ & $17 \%$ & $17 \%$ & $17 \%$ \\
\hline 30-39 years & $23 \%$ & $23 \%$ & $23 \%$ & $22 \%$ & $22 \%$ & $22 \%$ & $22 \%$ \\
\hline 40-49 years & $25 \%$ & $26 \%$ & $25 \%$ & $25 \%$ & $25 \%$ & $25 \%$ & $25 \%$ \\
\hline $50-59$ years & $22 \%$ & $22 \%$ & $22 \%$ & $23 \%$ & $23 \%$ & $23 \%$ & $22 \%$ \\
\hline 60 years or older & $13 \%$ & $13 \%$ & $12 \%$ & $14 \%$ & $13 \%$ & $13 \%$ & $13 \%$ \\
\hline \multicolumn{8}{|c|}{ Proportion of employees by educational level } \\
\hline $\begin{array}{l}\text { Lower secondary education } \\
\text { or less }\end{array}$ & $42 \%$ & $41 \%$ & $42 \%$ & $41 \%$ & $41 \%$ & $41 \%$ & $42 \%$ \\
\hline Upper secondary education & $41 \%$ & $40 \%$ & $41 \%$ & $41 \%$ & $41 \%$ & $41 \%$ & $40 \%$ \\
\hline Higher education & $15 \%$ & $16 \%$ & $15 \%$ & $15 \%$ & $16 \%$ & $15 \%$ & $15 \%$ \\
\hline $\begin{array}{l}\text { Unknown or no completed } \\
\text { education }\end{array}$ & $2 \%$ & $2 \%$ & $2 \%$ & $3 \%$ & $3 \%$ & $3 \%$ & $2 \%$ \\
\hline \multicolumn{8}{|c|}{ Number of employees in each firm } \\
\hline $1-9$ persons & $58 \%$ & $58 \%$ & $58 \%$ & $55 \%$ & $55 \%$ & $54 \%$ & $65 \%$ \\
\hline 10-24 persons & $23 \%$ & $22 \%$ & $23 \%$ & $24 \%$ & $24 \%$ & $24 \%$ & $19 \%$ \\
\hline 25-99 persons & $15 \%$ & $15 \%$ & $16 \%$ & $17 \%$ & $17 \%$ & $17 \%$ & $13 \%$ \\
\hline 100 persons or more & $4 \%$ & $4 \%$ & $4 \%$ & $5 \%$ & $5 \%$ & $5 \%$ & $4 \%$ \\
\hline $\begin{array}{l}\text { Average number of employees } \\
\text { in each firm }\end{array}$ & 23 & 23 & 23 & 25 & 25 & 25 & 20 \\
\hline Number of observations & 161,878 & 168,899 & 161,046 & 122,447 & 128,765 & 121,802 & 219,630 \\
\hline \multicolumn{8}{|c|}{ The WRT (wholesale and retail trade, repair of motor vehicles and motorcycles) sector } \\
\hline $\begin{array}{l}\text { Proportion of females of } \\
\text { total employees }\end{array}$ & $48 \%$ & $48 \%$ & $48 \%$ & $48 \%$ & $48 \%$ & $48 \%$ & $49 \%$ \\
\hline \multicolumn{8}{|c|}{ Proportion of employees by age } \\
\hline Under 30 years & $32 \%$ & $32 \%$ & $32 \%$ & $32 \%$ & $32 \%$ & $32 \%$ & $31 \%$ \\
\hline 30-39 years & $21 \%$ & $21 \%$ & $21 \%$ & $19 \%$ & $20 \%$ & $20 \%$ & $20 \%$ \\
\hline 40-49 years & $21 \%$ & $21 \%$ & $21 \%$ & $21 \%$ & $21 \%$ & $21 \%$ & $21 \%$ \\
\hline $50-59$ years & $17 \%$ & $17 \%$ & $17 \%$ & $17 \%$ & $17 \%$ & $17 \%$ & $17 \%$ \\
\hline 60 years or older & $10 \%$ & $10 \%$ & $10 \%$ & $11 \%$ & $11 \%$ & $11 \%$ & $10 \%$ \\
\hline \multicolumn{8}{|c|}{ Proportion of employees by educational level } \\
\hline $\begin{array}{l}\text { Lower secondary education } \\
\text { or less }\end{array}$ & $44 \%$ & $44 \%$ & $44 \%$ & $43 \%$ & $43 \%$ & $43 \%$ & $45 \%$ \\
\hline Upper secondary education & $39 \%$ & $39 \%$ & $39 \%$ & $40 \%$ & $40 \%$ & $40 \%$ & $38 \%$ \\
\hline Higher education & $15 \%$ & $15 \%$ & $15 \%$ & $15 \%$ & $15 \%$ & $15 \%$ & $15 \%$ \\
\hline $\begin{array}{l}\text { Unknown or no completed } \\
\text { education }\end{array}$ & $2 \%$ & $2 \%$ & $2 \%$ & $2 \%$ & $2 \%$ & $2 \%$ & $2 \%$ \\
\hline \multicolumn{8}{|c|}{ Number of employees in each firm } \\
\hline $1-9$ persons & $74 \%$ & $74 \%$ & $74 \%$ & $71 \%$ & $71 \%$ & $71 \%$ & $77 \%$ \\
\hline 10-24 persons & $20 \%$ & $20 \%$ & $20 \%$ & $23 \%$ & $23 \%$ & $23 \%$ & $18 \%$ \\
\hline
\end{tabular}


Table 1 (continued)

\begin{tabular}{|c|c|c|c|c|c|c|c|}
\hline 25-99 persons & $5 \%$ & $5 \%$ & $5 \%$ & $6 \%$ & $6 \%$ & $6 \%$ & $4 \%$ \\
\hline 100 persons or more & $0.4 \%$ & $0.4 \%$ & $0.4 \%$ & $0.4 \%$ & $0.5 \%$ & $0.4 \%$ & $0.4 \%$ \\
\hline $\begin{array}{l}\text { Average number of employ- } \\
\text { ees in each firm }\end{array}$ & 9 & 9 & 9 & 9 & 10 & 9 & 8 \\
\hline Number of observations & 584,938 & 596,731 & 582,449 & 437,247 & 447,127 & 435,135 & 780,498 \\
\hline
\end{tabular}

The PST (professional, scientific and technical activities) sector

\begin{tabular}{|c|c|c|c|c|c|c|c|}
\hline $\begin{array}{l}\text { Proportion of females of total } \\
\text { employees }\end{array}$ & $34 \%$ & $35 \%$ & $34 \%$ & $36 \%$ & $36 \%$ & $36 \%$ & $36 \%$ \\
\hline \multicolumn{8}{|l|}{ Proportion of employees by age } \\
\hline Under 30 years & $11 \%$ & $11 \%$ & $11 \%$ & $11 \%$ & $11 \%$ & $11 \%$ & $11 \%$ \\
\hline 30-39 years & $22 \%$ & $22 \%$ & $22 \%$ & $20 \%$ & $20 \%$ & $20 \%$ & $21 \%$ \\
\hline $40-49$ years & $27 \%$ & $27 \%$ & $27 \%$ & $26 \%$ & $26 \%$ & $26 \%$ & $27 \%$ \\
\hline $50-59$ years & $24 \%$ & $24 \%$ & $24 \%$ & $25 \%$ & $25 \%$ & $25 \%$ & $24 \%$ \\
\hline 60 years or older & $16 \%$ & $16 \%$ & $16 \%$ & $18 \%$ & $17 \%$ & $17 \%$ & $16 \%$ \\
\hline \multicolumn{8}{|c|}{ Proportion of employees by educational level } \\
\hline $\begin{array}{l}\text { Lower secondary education } \\
\text { or less }\end{array}$ & $16 \%$ & $16 \%$ & $16 \%$ & $17 \%$ & $16 \%$ & $17 \%$ & $17 \%$ \\
\hline Upper secondary education & $26 \%$ & $26 \%$ & $26 \%$ & $26 \%$ & $26 \%$ & $26 \%$ & $26 \%$ \\
\hline Higher education & $56 \%$ & $57 \%$ & $56 \%$ & $56 \%$ & $56 \%$ & $56 \%$ & $56 \%$ \\
\hline $\begin{array}{l}\text { Unknown or no completed } \\
\text { education }\end{array}$ & $1 \%$ & $1 \%$ & $1 \%$ & $1 \%$ & $1 \%$ & $1 \%$ & $1 \%$ \\
\hline \multicolumn{8}{|c|}{ Number of employees in each firm } \\
\hline $1-9$ persons & $84 \%$ & $84 \%$ & $84 \%$ & $81 \%$ & $81 \%$ & $81 \%$ & $86 \%$ \\
\hline 10-24 persons & $11 \%$ & $11 \%$ & $11 \%$ & $13 \%$ & $13 \%$ & $13 \%$ & $10 \%$ \\
\hline 25-99 persons & $4 \%$ & $4 \%$ & $4 \%$ & $5 \%$ & $5 \%$ & $5 \%$ & $4 \%$ \\
\hline 100 persons or more & $1 \%$ & $1 \%$ & $1 \%$ & $1 \%$ & $1 \%$ & $1 \%$ & $1 \%$ \\
\hline $\begin{array}{l}\text { Average number of employees } \\
\text { in each firm }\end{array}$ & 7 & 7 & 7 & 9 & 9 & 9 & 7 \\
\hline Number of observations & 206,614 & 211,640 & 204,746 & 140,533 & 144,447 & 139,132 & 293,311 \\
\hline
\end{tabular}

(1) S1: Subsample of observations when using OLS or FE regression, where the log of the productivity level is used as the dependent variable. (2) S2: Subsample of observations when using OLS or FE regression, where the log of the wage level is used as the dependent variable. (3) S3: Subsample of observations when using OLS or FE regression, where the difference between the log of the productivity level and the log of the wage level is used as the dependent variable. (4) S4: Subsample of observations when using two-step GMM regression in first differences, where the first difference of the log of the productivity level is used as the dependent variable. (5) S5: Subsample of observations when using two-step GMM regression in first differences, where the first difference of the log of the wage level is used as the dependent variable. (6) S6: Subsample of observations when using two-step GMM regression in first differences, where the difference between the first difference of the log of the productivity level and the first difference of the log of the wage level is used as the dependent variable. (7) Full sample: All observations in one of the sectors in the final sample are used

firms that have 1-9 employees is much lower among manufacturing firms than among firms in the two other sectors, and this proportion is highest among firms in the PST sector. Firms in the manufacturing and WRT sectors have about the same proportion of observations concerning those with 10-24 employees, while 
this proportion is much lower in the PST sector. Manufacturing firms have the highest proportions of firms with 25-99 employees and at least 100 employees. The proportion of those with 25-99 employees is about the same in the two service sectors, and the lowest proportion of those with at least 100 employees is found among firms in the WRT sector. Given these proportions, it is not surprising that the average number of employees in each firm is much higher in the manufacturing sector than in each of the service sectors.

The table shows that the proportions of observations concerning employees in the 50-59 age group and those that are 60 years or older are highest among firms in the PST sector, and lowest among firms in the WRT sector. Consequently, the proportion of the youngest age group is lowest in the PST sector, and highest in the other service sector. The proportion of employees in the 40-49 age group is lowest in the WRT sector, while this proportion is about the same in the two other sectors. There are small differences in the proportion of those in the 30-39 age group between the three sectors. There are very few observations where the age of employees is unknown $(0.0003 \%$ in the full sample in the manufacturing sector, $0.0001 \%$ in the full sample in the WRT sector, and $0.0028 \%$ in the full sample in the PST sector).

We find that the proportion of females is highest in the WRT sector, and lowest in the manufacturing sector. For a very small number of observations, we lack information on the employees' gender. The proportion of employees with unknown gender is the same as the proportion of those with unknown age in each of the three sectors.

Over half of the observations among firms in the PST sector concern employees with higher education as their highest attained educational level, which is the highest proportion when we compare the three sectors. The proportions of employees with lower secondary education or less and upper secondary education are much lower in the PST sector than in the two other sectors. There are small differences in the proportions of employees in the different groups of educational level between manufacturing firms and firms in the WRT sector.

Figure 1 shows that the productivity level in each sector is lowest among firms where the average age of employees is either under 30 years or 60 years or older, and highest among those where the average age is in the 40-49 age group. The relative differences in the log of the productivity level between the 30-39, 40-49 and 50-59 age groups are, however, smaller in the PST sector than in the two other sectors. The wage level in the manufacturing and PST sectors is also lowest among firms where the average age of employees is either in the youngest or oldest age group, and highest in the 40-49 age group. In the WRT sector, the wage level decreases with increasing age group. The productivity-wage gap in the manufacturing sector is highest among firms where the average age of employees is in the oldest age group, and about the same in the other age groups. In the WRT sector, the gap increases with increasing age group. The gap in the PST sector is highest among those where the average age is either in the youngest or oldest age group, and lowest in the 40-49 age group. In Sect. 7.1, we examine whether these relationships between the productivity level, the wage level, the productivity-wage gap and employees' age still hold after control for several firm and other employee characteristics. 


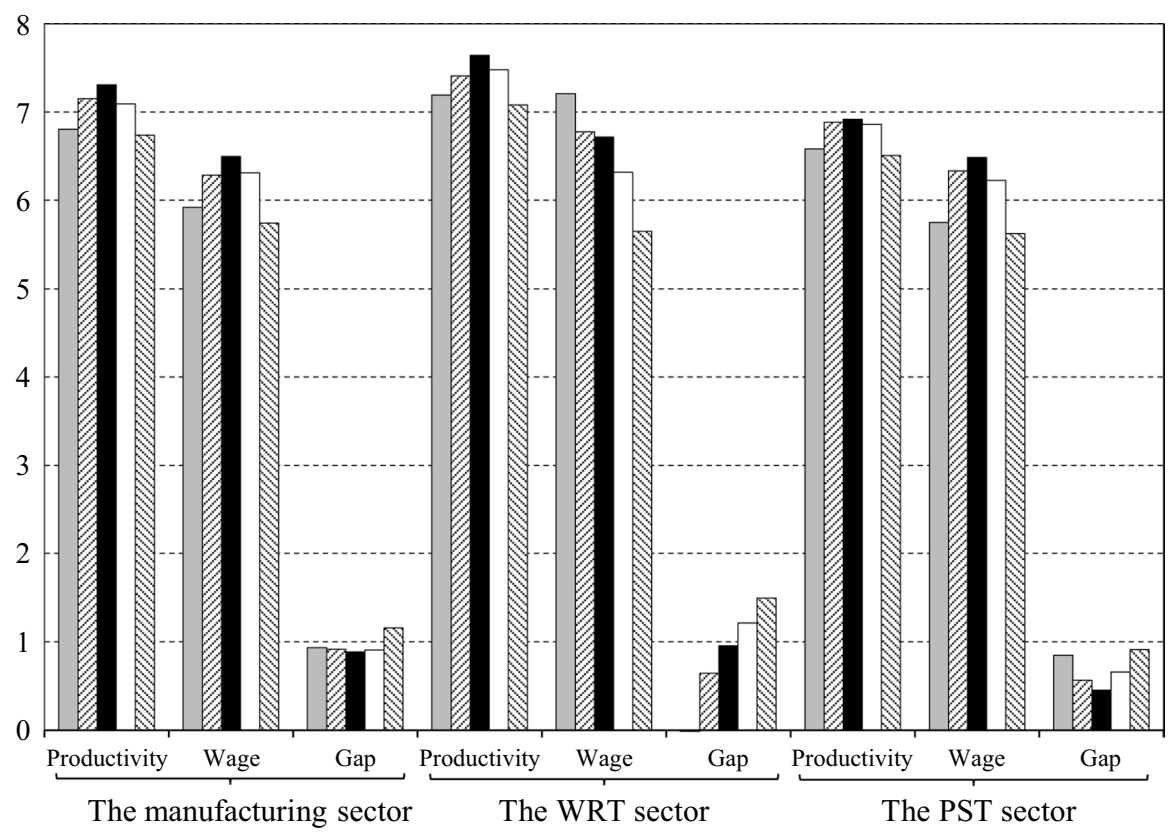

$\square$ Under 30 years $\otimes 30-39$ years $\square 40-49$ years $\square 50-59$ years $⿴ 60$ years or older

Fig. 1 The values of the dependent variables by type of sector and type of employees' age, averages for the period 2000-2016 Notes (1) 'Productivity': Log of the productivity level. (2) 'Wage': Log of the wage level. (3) 'Gap': The productivity-wage gap, measured by the difference between the $\log$ of the productivity level and the log of the wage level. 4) The figure is based on observations of the average age of employees in each firm for the period 2000-2016

\section{Estimation Results}

Tables 2, 3, 4 show the estimated effects of explanatory variables on the dependent variables. The estimated results in the columns 'productivity', 'wage' and 'gap' in each table are based on the three regression techniques described in Sect. 5.4. In the 'productivity' estimations, the dependent variable is the log of the productivity level when using OLS or FE, or the first difference of this level when using GMM. The dependent variable in the 'wage' estimations is the log of the wage level when using OLS or FE, or the first difference of this level when using GMM. In the 'gap' estimations, the dependent variable is the productivity-wage gap (i.e. the difference between the log of the productivity level and the log of the wage level) when using OLS or FE, or the first difference of the gap variable when using GMM. Due to space limitations, the results from the effects of the dummies for industrial sectors, a firm's location and years of registration are not shown in the tables. 


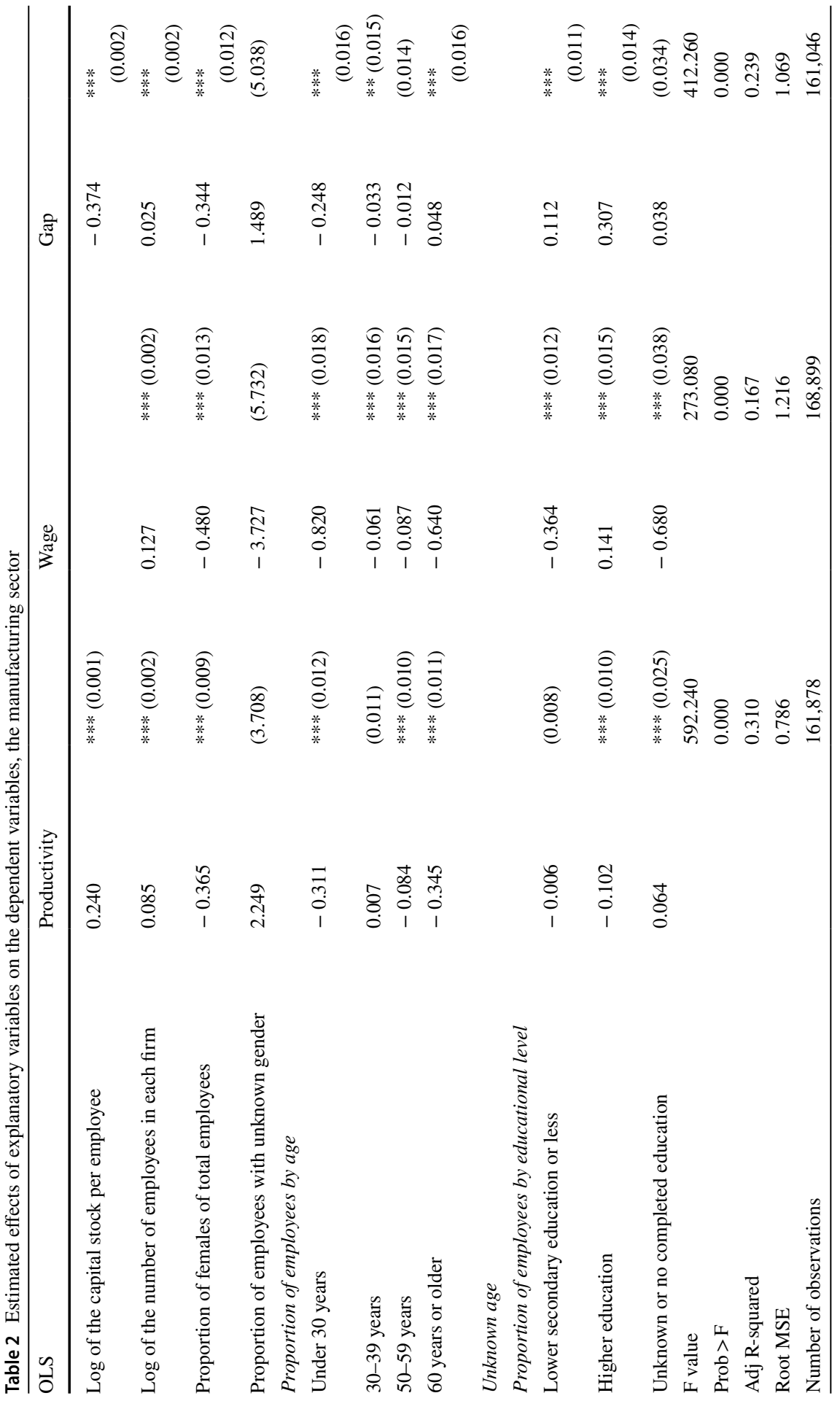




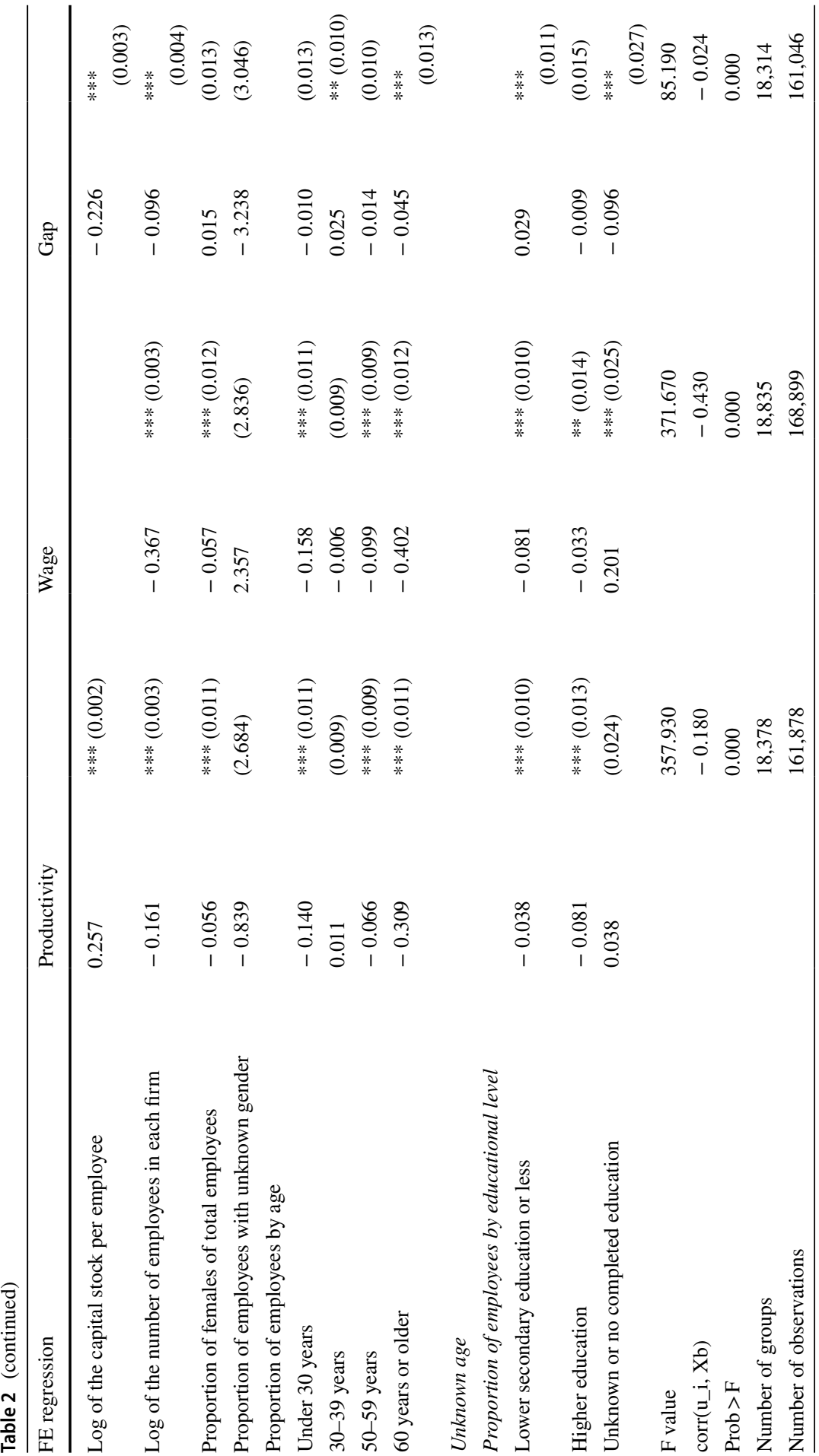




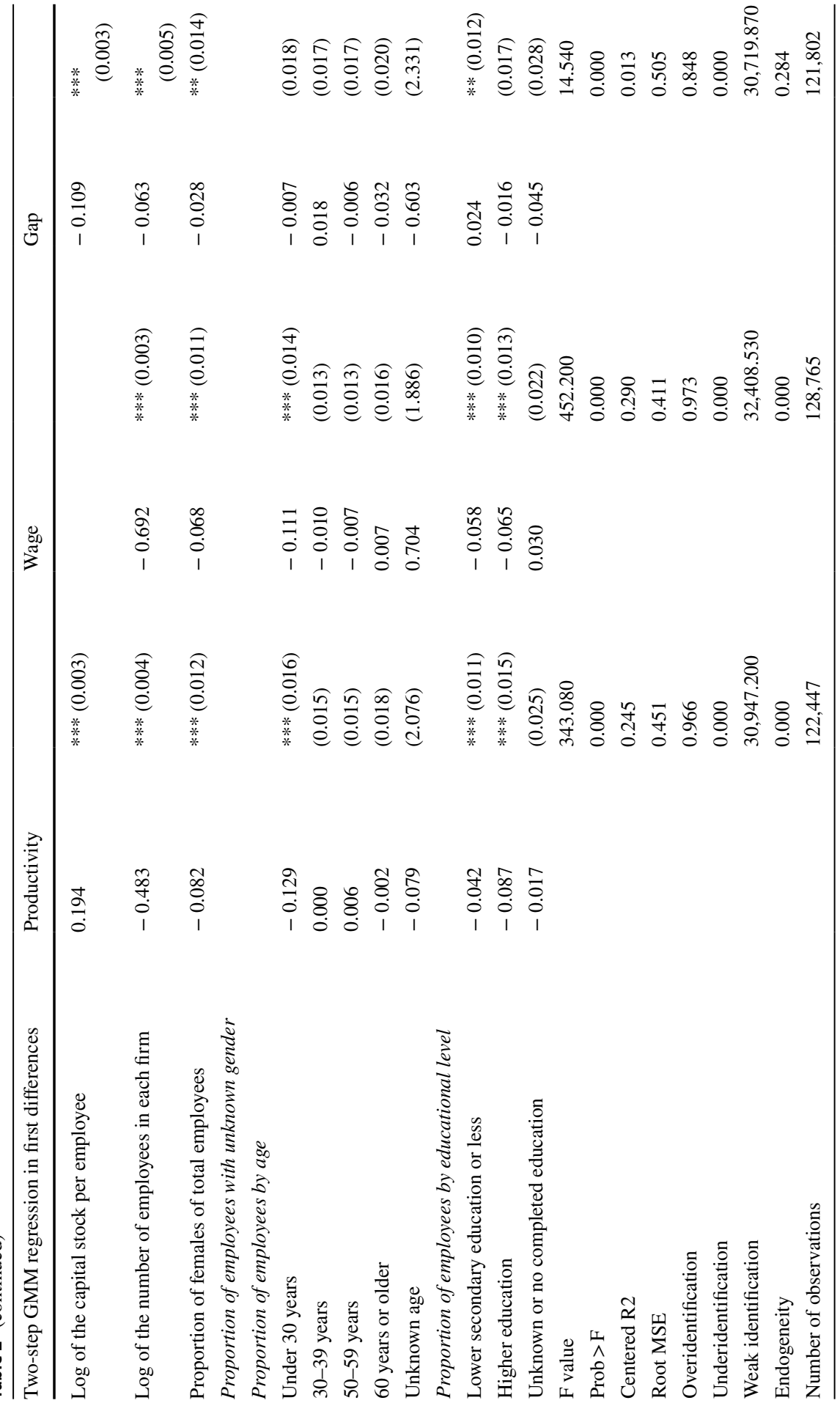




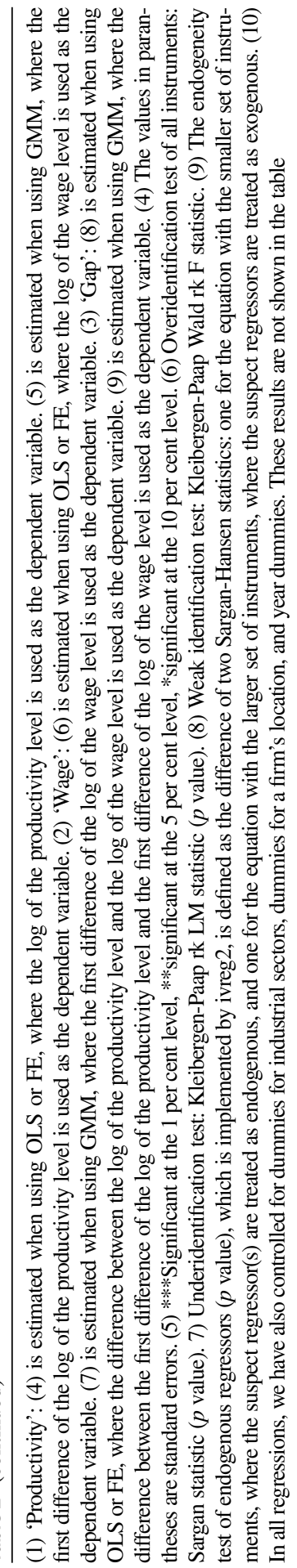




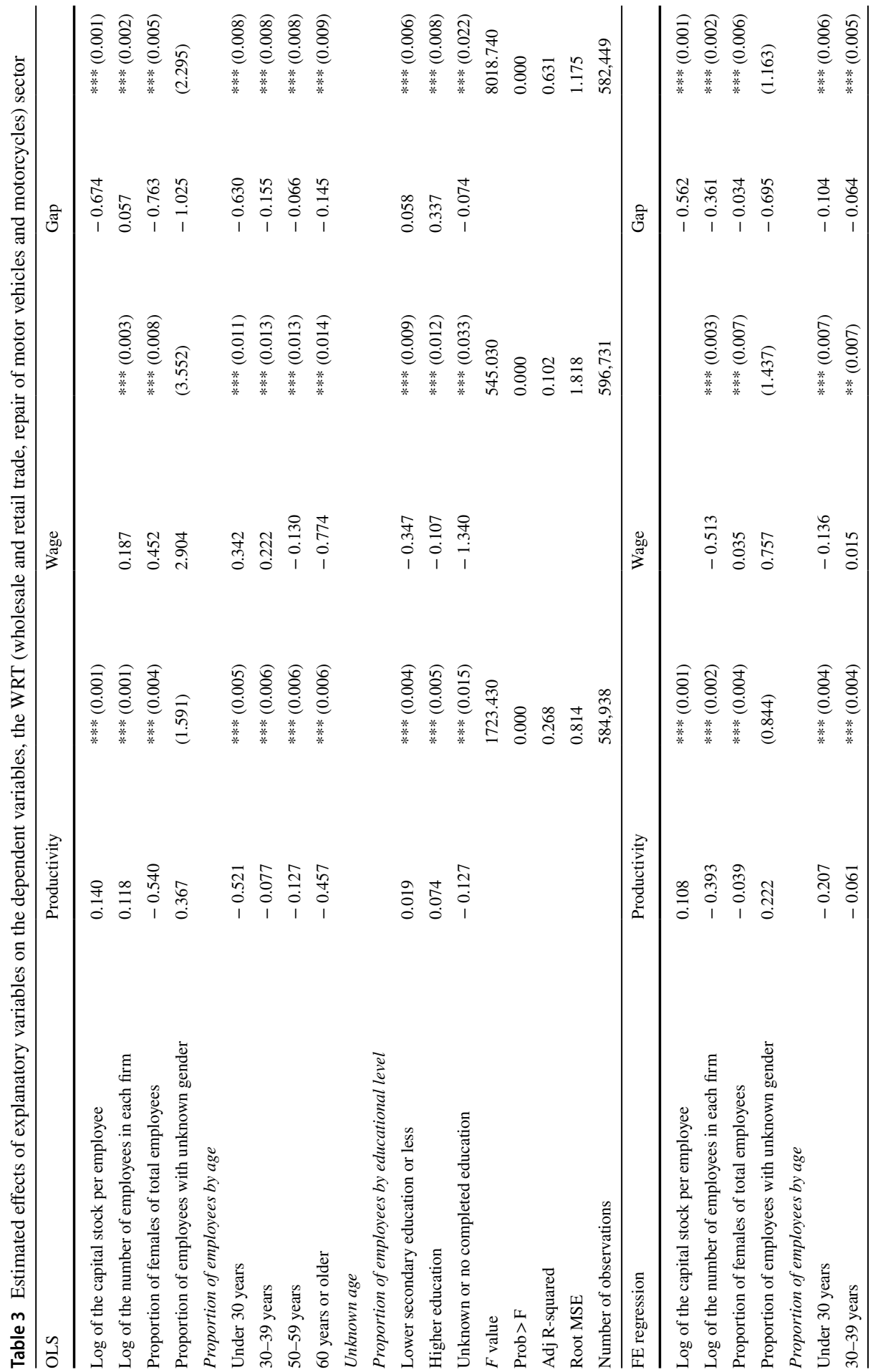




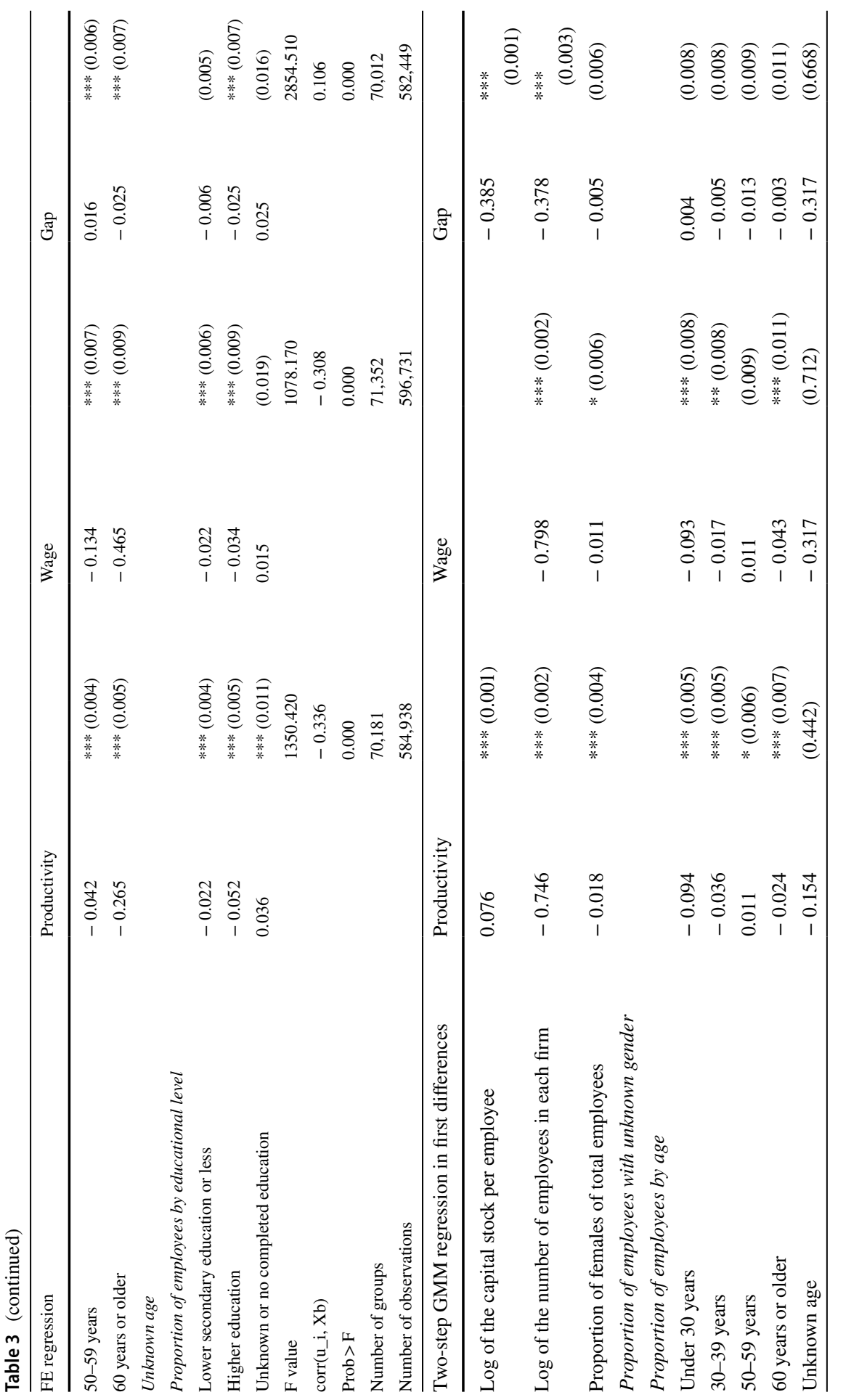




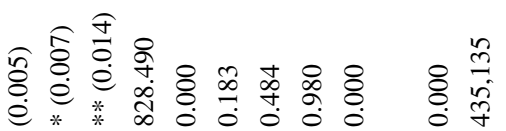

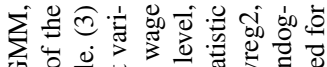

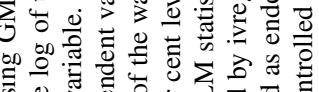

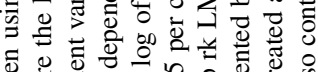

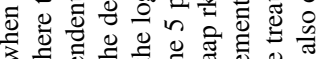

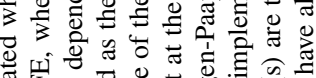

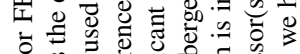

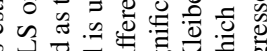

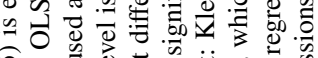

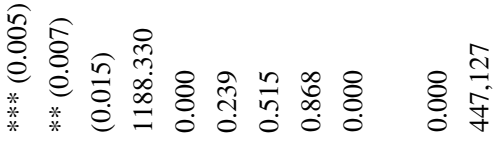
厄)

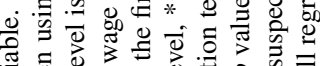

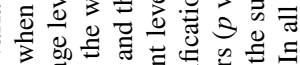

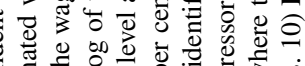

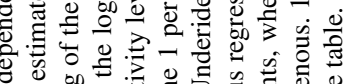

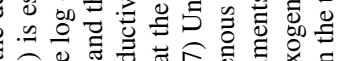
6ิ రृष्ठ

$\begin{array}{lll}n & 0 \\ 0 & 0 & 0 \\ 0 & 0 & 0 \\ 1 & 1 & 0\end{array}$

8
8
8
8
8
0

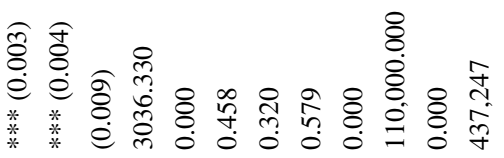
3 ए

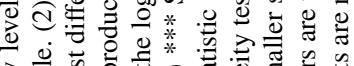

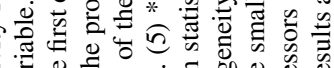

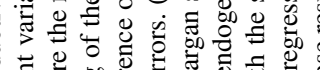
馬

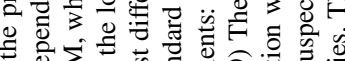

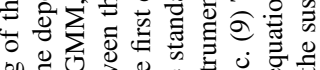
車

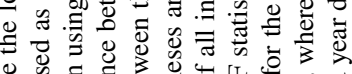

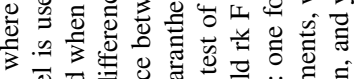

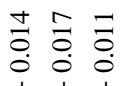
\begin{tabular}{l}
8 \\
8 \\
8 \\
8 \\
0 \\
0 \\
\hline
\end{tabular}

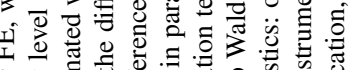

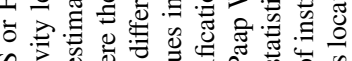

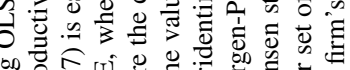

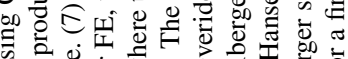

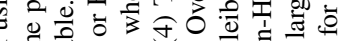
ฮี

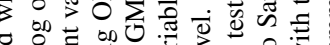

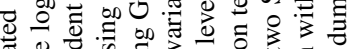

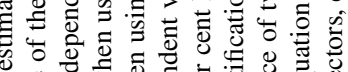

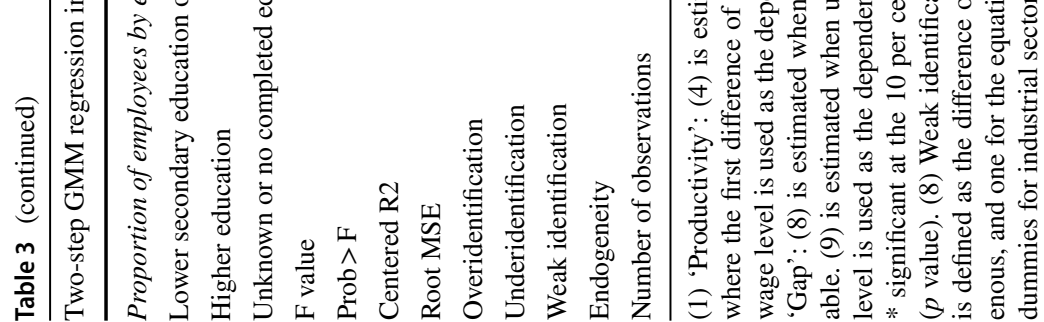


Table 4 Estimated effects of explanatory variables on the dependent variables, the PST (professional, scientific and technical activities) sector

\begin{tabular}{|c|c|c|c|c|c|c|}
\hline \multirow{2}{*}{$\frac{\text { OLS }}{\text { Log of the capital stock per employee }}$} & \multicolumn{2}{|c|}{ Productivity } & \multicolumn{2}{|l|}{ Wage } & \multicolumn{2}{|l|}{ Gap } \\
\hline & 0.263 & $* * *(0.001)$ & & & -0.239 & $* * *(0.002)$ \\
\hline $\begin{array}{l}\text { Log of the number of employees in } \\
\text { each firm }\end{array}$ & 0.068 & $* * *(0.002)$ & 0.293 & $* * *(0.003)$ & -0.180 & $* * *(0.002)$ \\
\hline Proportion of females of total employees & -0.193 & $* * *(0.006)$ & -0.289 & $* * *(0.008)$ & -0.134 & $* * *(0.007)$ \\
\hline $\begin{array}{l}\text { Proportion of employees with unknown } \\
\text { gender }\end{array}$ & 0.355 & $(0.400)$ & 0.764 & $(0.573)$ & -0.556 & $(0.517)$ \\
\hline \multicolumn{7}{|l|}{ Proportion of employees by age } \\
\hline Under 30 years & -0.351 & **** $(0.010)$ & -0.643 & $* * *(0.014)$ & 0.021 & $*(0.013)$ \\
\hline $30-39$ years & -0.083 & $* * *(0.007)$ & -0.079 & $* * *(0.010)$ & -0.087 & $* * *(0.009)$ \\
\hline $50-59$ years & -0.086 & $* * *(0.006)$ & -0.067 & $* * *(0.009)$ & 0.004 & (0.008) \\
\hline 60 years or older & -0.455 & $* * *(0.007)$ & -0.653 & $* * *(0.010)$ & 0.147 & $* * *(0.009)$ \\
\hline \multicolumn{7}{|l|}{ Unknown age } \\
\hline \multicolumn{7}{|l|}{ Proportion of employees by educational level } \\
\hline Lower secondary education or less & -0.048 & $* * *(0.008)$ & -0.232 & $* * *(0.011)$ & 0.078 & $* * *(0.010)$ \\
\hline Higher education & -0.008 & $(0.006)$ & 0.145 & $* * *(0.008)$ & -0.041 & $* * *(0.007)$ \\
\hline Unknown or no completed education & -0.148 & $* * * *(0.024)$ & -0.386 & *** $(0.034)$ & 0.105 & $* * *(0.031)$ \\
\hline F value & & 618.870 & & 384.280 & & 415.090 \\
\hline Prob $>F$ & & 0.000 & & 0.000 & & 0.000 \\
\hline Adj R-squared & & 0.272 & & 0.183 & & 0.202 \\
\hline Root MSE & & 0.798 & & 1.145 & & 1.033 \\
\hline Number of observations & & 206,614 & & 211,640 & & 204,746 \\
\hline FE regression & \multicolumn{2}{|c|}{ Productivity } & \multicolumn{2}{|l|}{ Wage } & \multicolumn{2}{|l|}{ Gap } \\
\hline Log of the capital stock per employee & 0.340 & $* * *(0.002)$ & & & -0.108 & $* * *(0.002)$ \\
\hline $\begin{array}{l}\text { Log of the number of employees in } \\
\text { each firm }\end{array}$ & -0.076 & $* * *(0.003)$ & -0.185 & $* * *(0.004)$ & -0.124 & $* * *(0.004)$ \\
\hline Proportion of females of total employees & -0.084 & $* * *(0.008)$ & -0.125 & $* * *(0.010)$ & 0.004 & $(0.010)$ \\
\hline $\begin{array}{l}\text { Proportion of employees with unknown } \\
\text { gender }\end{array}$ & -3.924 & $(13.493)$ & 2.188 & $(16.738)$ & -0.205 & $(15.600)$ \\
\hline \multicolumn{7}{|l|}{ Proportion of employees by age } \\
\hline Under 30 years & -0.243 & $* * *(0.010)$ & -0.333 & $* * *(0.012)$ & 0.018 & $(0.011)$ \\
\hline $30-39$ years & -0.091 & $* * * *(0.007)$ & -0.101 & $* * *(0.009)$ & -0.007 & $(0.008)$ \\
\hline $50-59$ years & -0.005 & $(0.007)$ & -0.043 & $* * *(0.008)$ & 0.038 & $* * *(0.008)$ \\
\hline 60 years or older & -0.233 & $* * * *(0.009)$ & -0.395 & $* * *(0.011)$ & 0.061 & $* * *(0.011)$ \\
\hline \multicolumn{7}{|l|}{ Unknown age } \\
\hline \multicolumn{7}{|l|}{ Proportion of employees by educational level } \\
\hline Lower secondary education or less & -0.068 & $* * *(0.011)$ & -0.132 & $* * *(0.014)$ & 0.028 & $* *(0.013)$ \\
\hline Higher education & 0.011 & $(0.009)$ & 0.077 & $* * *(0.011)$ & -0.049 & $* * *(0.011)$ \\
\hline Unknown or no completed education & -0.048 & $*(0.028)$ & -0.074 & $* *(0.034)$ & 0.033 & $(0.033)$ \\
\hline F value & & 379.580 & & 196.460 & & 51.660 \\
\hline corr $\left(\mathrm{u} \_\mathrm{i}, \mathrm{Xb}\right)$ & & -0.169 & & -0.204 & & 0.168 \\
\hline Prob $>F$ & & 0.000 & & 0.000 & & 0.000 \\
\hline Number of groups & & 31,761 & & 32,149 & & 31,609 \\
\hline Number of observations & & 206,614 & & 211,640 & & 204,746 \\
\hline
\end{tabular}


Table 4 (continued)

\begin{tabular}{|c|c|c|c|c|c|c|}
\hline \multirow{2}{*}{$\begin{array}{l}\text { Two-step GMM regression in first } \\
\text { differences } \\
\text { Log of the capital stock per employee }\end{array}$} & \multicolumn{2}{|c|}{ Productivity } & \multicolumn{2}{|l|}{ Wage } & \multicolumn{2}{|l|}{ Gap } \\
\hline & 0.303 & $* * *(0.003)$ & & & 0.041 & $* * *(0.003)$ \\
\hline $\begin{array}{l}\text { Log of the number of employees in } \\
\text { each firm }\end{array}$ & -0.407 & $* * *(0.005)$ & -0.577 & $* * *(0.005)$ & -0.051 & $* * *(0.005)$ \\
\hline Proportion of females of total employees & -0.056 & $* * *(0.009)$ & -0.084 & $* * *(0.010)$ & 0.013 & $(0.011)$ \\
\hline \multicolumn{7}{|c|}{ Proportion of employees with unknown gender } \\
\hline \multicolumn{7}{|l|}{ Proportion of employees by age } \\
\hline Under 30 years & -0.126 & $* * *(0.015)$ & -0.199 & *** $(0.016)$ & 0.061 & $* * *(0.017)$ \\
\hline 30-39 years & -0.027 & $* *(0.012)$ & -0.043 & $* * *(0.013)$ & 0.018 & $(0.014)$ \\
\hline $50-59$ years & 0.034 & $* * *(0.012)$ & 0.024 & $*(0.013)$ & 0.003 & $(0.014)$ \\
\hline 60 years or older & 0.009 & $(0.015)$ & 0.003 & $(0.017)$ & -0.002 & $(0.018)$ \\
\hline Unknown age & -7.232 & $(13.233)$ & 0.357 & $(14.784)$ & 0.279 & $(15.446)$ \\
\hline \multicolumn{7}{|c|}{ Proportion of employees by educational level } \\
\hline Lower secondary education or less & -0.011 & $(0.012)$ & -0.068 & $* * *(0.014)$ & 0.041 & $* * *(0.015)$ \\
\hline Higher education & 0.028 & $* * *(0.011)$ & 0.041 & $* * *(0.012)$ & -0.008 & $(0.012)$ \\
\hline Unknown or no completed education & 0.029 & $(0.028)$ & -0.004 & $(0.031)$ & -0.001 & $(0.033)$ \\
\hline F value & & 379.510 & & 191.870 & & 7.570 \\
\hline Prob $>$ F & & 0.000 & & 0.000 & & 0.000 \\
\hline Centered R2 & & 0.248 & & 0.138 & & 0.006 \\
\hline Root MSE & & 0.485 & & 0.541 & & 0.566 \\
\hline Overidentification & & 0.591 & & 0.560 & & 0.962 \\
\hline Underidentification & & 0.000 & & 0.000 & & 0.000 \\
\hline Weak identification & & $30,671.450$ & & $31,550.080$ & & $30,306.430$ \\
\hline Endogeneity & & 0.000 & & 0.000 & & 0.005 \\
\hline Number of observations & & 140,533 & & 144,447 & & 139,132 \\
\hline
\end{tabular}

(1) 'Productivity': (4) is estimated when using OLS or FE, where the log of the productivity level is used as the dependent variable. (5) is estimated when using GMM, where the first difference of the log of the productivity level is used as the dependent variable. (2) 'Wage': (6) is estimated when using OLS or FE, where the log of the wage level is used as the dependent variable. (7) is estimated when using GMM, where the first difference of the log of the wage level is used as the dependent variable. (3) 'Gap': (8) is estimated when using OLS or FE, where the difference between the log of the productivity level and the $\log$ of the wage level is used as the dependent variable. (9) is estimated when using GMM, where the difference between the first difference of the log of the productivity level and the first difference of the $\log$ of the wage level is used as the dependent variable. (4) The values in parantheses are standard errors. (5) ***Significant at the 1 per cent level, **significant at the 5 per cent level, *significant at the 10 per cent level. (6) Overidentification test of all instruments: Sargan statistic ( $p$ value). (7) Underidentification test: Kleibergen-Paap rk LM statistic ( $p$ value). 8) Weak identification test: Kleibergen-Paap Wald rk F statistic. (9) The endogeneity test of endogenous regressors ( $p$ value), which is implemented by ivreg2, is defined as the difference of two Sargan-Hansen statistics: one for the equation with the smaller set of instruments, where the suspect regressor(s) are treated as endogenous, and one for the equation with the larger set of instruments, where the suspect regressors are treated as exogenous. (10) In all regressions, we have also controlled for dummies for industrial sectors, dummies for a firm's location, and year dummies. These results are not shown in the table 


\subsection{The Effects of the Key Regressors}

We see from the 'productivity' column in Table 2 that a manufacturing firm's productivity level is negatively affected by the proportions of employees under 30 years, 50-59 years and 60 years or older in the OLS and FE regressions, where the reference category is the proportion of employees between 40 and 49 years. There is a negative effect of the proportion of those in the youngest age group on the productivity level among manufacturing firms in the GMM regression, but no significant effects of the proportions of the other age groups. The proportion of the 30-39 age group has no significant effect in the OLS and FE regressions.

Table 3 shows that the productivity level in the WRT sector is negatively affected by the proportions of employees in the four age groups (in the table) in all three regressions. There is one exception: This level is positively affected by the proportion of the 50-59 age group in the GMM regression, but the effect is only significant at the 10 per cent level. As shown in Table 4, all four age-related proportions of employees in the PST sector have a negative effect on the productivity level in the OLS and FE regressions, except that this level is not significantly affected by the proportion of those in the 50-59 age group in the FE regression. In the GMM regression, we find negative effects of the proportions of the two youngest age groups, a positive effect of the proportion of the 50-59 age group and a non-significant effect of the proportion of the oldest age group in the PST sector.

Based on the GMM regressions, firms with a high ratio between the proportion of employees under 30 years and the proportion of employees in the 40-49 age group have a lower productivity level than firms with a low ratio, ceteris paribus. This holds for each of the three sectors. These results are to some extent in line with the descriptive statistics in Sect. 6, in the sense that the observed productivity level in each sector is lowest among firms where the average age of employees is either in the youngest or oldest age group, and highest among those where the average age is between 40 and 49 years. The estimation results indicate that the average individual productivity level is higher among workers in their $40 \mathrm{~s}$ than among the youngest employees. ${ }^{6}$

Regarding the wage level, we find that the proportions of the two youngest age groups have a negative effect on this level in all regressions in the PST sector. The two oldest age groups have a negative effect on the wage level in the OLS and FE regressions, but a non-significant effect in the GMM regression (at the 5 per cent level), in this sector. The level is negatively affected by the proportions of the youngest and oldest workers in the FE and GMM regressions in the WRT sector. In the OLS regression in the WRT sector, there is also a negative effect of the proportions of the two oldest age groups, but a positive effect of the proportions of the two youngest age groups. In the manufacturing sector, the wage level is negatively affected by the proportion of the youngest age group in all regressions, and

\footnotetext{
${ }^{6}$ Individual productivity is measured as the workers' marginal impact on the firm's productivity level (Skirbekk 2004).
} 
negatively affected by the proportions of the two oldest age groups in the OLS and FE regressions.

The gap estimations show that the estimates are highly sensitive with respect to type of regression technique in each sector. We see that the proportion of employees in the oldest age group has a positive effect on the productivity-wage gap among firms in the PST sector, and a negative effect on the gap in the WRT sector, when using OLS or FE. In the manufacturing sector, this effect is negative when using FE and positive when using OLS. Based on the GMM regressions, the proportion of those in the youngest age group has a positive effect on the productivity-wage gap in the PST sector, but a non-significant effect in the two other sectors. None of the proportions of the other age groups than the youngest have a significant effect on the gap in any of the sectors when using GMM.

We conclude that the estimated results of the wage level when using GMM are to some extent in line with the descriptive statistics for the manufacturing and PST sectors, but to a small extent in line with these statistics for the WRT sector. In the manufacturing and PST sectors, the observed wage level is lower among firms where the average age of employees is either in one of the two youngest or one of the two oldest age groups than among those where the average age is in the 40-49 age group. Furthermore, the observed wage level in the WRT sector is relatively higher among firms where the average age is in one of the two youngest age groups, and relatively lower among those where the average age is in one of the two oldest age groups.

The results of the productivity-wage gap when using GMM are also to some extent in line with the descriptive statistics for the manufacturing and PST sectors, but to a small extent in line with these statistics for the WRT sector. In the manufacturing sector, the observed gap is higher among firms where the average age is in the oldest age group than among those where the average age is between 40 and 49 years, but there are very small differences in the observed gap between the age groups if one disregards the oldest age group. The observed gap in the WRT sector is highest for the two oldest age groups and lowest for the two youngest age groups. In the PST sector, the observed gap is higher for the two youngest or two oldest age groups than for the 40-49 age group.

To summarise, the relationship between the productivity level and employees' age in Sect. 6 applies to some extent after control for several firm and other employee characteristics (when using GMM). This also applies to some extent to the relationships between the wage level, the productivity-wage gap and employees' age for the manufacturing and PST sectors, but to a small extent for the WRT sector (using GMM).

Our results when using GMM give some support for the hypothesis H1 for the WRT sector, while we find no support for this hypothesis for the manufacturing and PST sectors, where those between 40 and 49 years are defined as middle-aged employees. The GMM results give some support for $\mathrm{H} 2$ for the manufacturing and PST sectors, but little support for the WRT sector. These results give some support for $\mathrm{H} 3$ for the PST sector, while we find no support for this hypothesis for the manufacturing and WRT sectors. We find that a firm's productivity level is negatively affected by its proportion of the oldest workers in the WRT sector. The wage level is negatively affected by the proportion of the youngest workers in all sectors, 


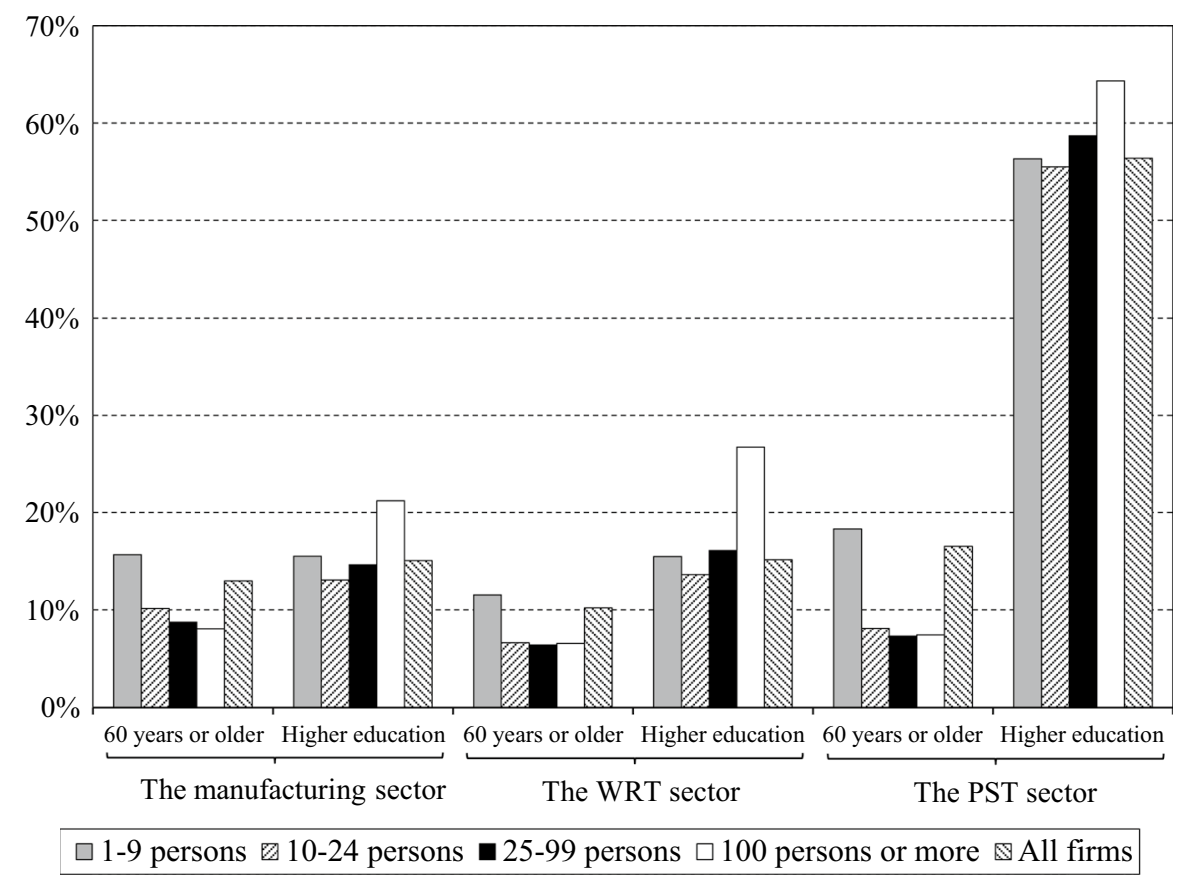

Fig. 2 The proportions of the oldest employees (60 years or older) and employees with higher education by type of sector and type of firm size, averages for the period 2000-2016

while this level is negatively affected by the proportion of the oldest workers in the WRT sector (and not significantly affected in the two other sectors). The productivity-wage gap is positively affected by the proportion of the youngest employees in the PST sector, but the gap is not significantly affected by the proportion of the oldest employees in this sector. In the two other sectors, there are non-significant effects of the proportions of the youngest and oldest employees on the gap.

In the light of the theoretical arguments set out in Sect. 2, productivity declines at older ages can be related to reductions in cognitive abilities. However, we find that the age-earnings profile is not characterised by a significant increase in wage levels until relatively late in the working life after control for several firm and other employee characteristics. We also find that the productivity-wage gap does not decrease at older ages in any of the sectors when using GMM.

The differences in the estimated effects of the proportion of the oldest employees on the productivity level between the WRT sector and the two other sectors (when using GMM) may be partly explained by the relatively low educational level among the oldest employees in small firms in the WRT sector, and partly explained by the relatively high proportion of persons with a manual occupation in this sector. 
Figure 2 shows that the proportion of the oldest age group is lowest in the WRT sector and highest in the PST sector among all firms. We see that this proportion is much higher in the PST sector than in the WRT sector among the smallest firms (1-9 employees), but about the same among firms in each of the three largest firm size groups. The proportion of employees with higher education is about the same in the manufacturing and WRT sectors among firms in each of the three smallest firm size groups, but relatively higher in the WRT sector among the largest firms (100 employees or more). In the PST sector, the proportion of employees with higher education is much higher than in the two other sectors among firms in each of the four firm size groups.

Both the relatively low proportions of the oldest employees and employees with higher education among small firms in the WRT sector indicate that there may be a selection of older employees with a relatively low individual productivity potential into small firms in this sector. This can partly explain the negative effect of the proportion of the oldest employees on the productivity level in the WRT sector, since most of the firms in this sector are small firms. Another explanation is the relatively high proportion of persons with a manual occupation in the WRT sector. Persons with a manual occupation are either employed as 'clerical support workers', 'service and sales workers', 'skilled agricultural, forestry and fishery workers', 'craft and related trades workers', or 'plant and machine operators and assemblers'. According to Statistics Norway's Labour Force Survey (LFS) of employed persons in 2016, ${ }^{7}$ the proportion of persons with a manual occupation is higher in the WRT sector $(65 \%)$ than in the manufacturing sector $(56 \%)$, and much higher than in a service sector which includes both real estate activities, administrative and support service activities, and the PST sector $(26 \%) .{ }^{8}$ About two-thirds of the persons with a manual occupation in the WRT sector are service and sales workers. The proportion of professionals is lower in the WRT sector (5\%) than in the manufacturing sector (9\%), and much higher in the service sector $(31 \%)$ than in the two other sectors. Therefore, the oldest workers can have a challenge to keep up with the individual productivity of younger ones, since physical strength and health fall as workers grow older (see Sect. 2). Børing \& Grøgaard (2021) find that there is a clear tendency for professionals to have a higher individual productivity potential score than workers with a manual occupation. ${ }^{9}$ The composition of employees by occupation can therefore indicate that employees in the WRT sector have the lowest individual productivity potential among the three sectors. In the analysis, we have not controlled for differences in employees' occupation between the sectors. The reason is that we have no information about a worker's occupation in the combined data.

The results of the productivity level in our analysis (using GMM) are to some extent in line with the studies by Skirbekk (2004) and Van Ours (2009, when analysing individual-level data on running) for the WRT sector, and with Aubert \& Crépon

\footnotetext{
7 The LSF covers persons aged 15-74 years.

8 Based on the LFS, it is not possible to distinguish between the three service sectors.

9 In Børing \& Grøgaard (2021), persons with a manual occupation also include persons employed in 'elementary occupations'.
} 
(2006) and Van Ours (2009, when using individual-level data on publishing in economics journals) for the two other sectors. Our productivity results are to a small extent in line with Börsch-Supan \& Weiss (2016), Cataldi et al. (2012), Dostiemailto, (2011), Göbel \& Zwick (2012), Hellerstein \& Neumark (2007) and Van Ours $\&$ Stoeldraijer (2011). The results of the productivity-wage gap are to some extent in line with the studies by Aubert \& Crépon (2006), Töpfer (2020), Van Ours (2009) and Van Ours \& Stoeldraijer (2011) and, but not in line with Cataldi et al. (2012).

In Sect. 6, we concluded that there is an overrepresentation of small firms in the full sample compared with the subsamples. This applies in particular to the manufacturing sector. Therefore, we have conducted a sensitively analysis for each sector in order to examine whether this overrepresentation may affect the estimation results. This analysis is done by comparing the results in Tables 2, 3, 4 with similar results for small firms, where we only focus on the effects of the proportions of employees in the different age groups, and only use two-step GMM regression. If we limit the number of observations in the manufacturing and PST sectors to firms with 1-9 employees, then the overidentification test of all instruments (Sargan statistic, p-value) reports that 'equation exactly identified'. This test reports the same if we limit the number of observations in the PST sector to firms with 1-24 employees. As a result of this, we compare the results of the GMM regressions in Tables 2, 3, 4 with similar results for (i) firms in the manufacturing sector with 1-24 employees, (ii) firms in the WRT sector with 1-9 employees, and (iii) firms in the PST sector with 1-99 employees. We find the same positive and negative significant effects of the proportions of the age groups for firms in the categories (i)-(iii) as the corresponding effects in the tables (at the 5 per cent level). The same positive and negative effects are also found for manufacturing firms with 1-9 employees, and firms in the PST sector with 1-9 or 1-24 employees. There are some exceptions: The effect of the proportion of the 30-39 age group on the productivity level is not significant, and the effect of the proportion of the 50-59 age group on the wage level is positive and significant, among firms in the PST sector with 1-9 or 1-24 employees (5 per cent level). These results indicate that the estimated effects of the proportions of the age groups in each sector are to a small extent sensitive to the overrepresentation of small firms.

Furthermore, we have conducted a sensitively analysis for each sector in order to examine to what extent the estimated effects of the proportions of the age groups on the productivity-wage gap are sensitive to the inclusion of different control variables. If we omit employee characteristics as gender and educational level (i.e. the proportion of females of total employees, the proportion of employees with unknown gender, and the proportions of employees at different educational levels), we find the same positive and negative significant effects of the proportions of the age groups as the corresponding effects in Tables 2, 3, 4. These estimated effects are therefore not very sensitive to the inclusion of gender and educational level as control variables. This is interesting since there are large differences between the three sectors in terms of the proportion of females of total employees and the proportions of employees at different educational levels (see Sect. 6). If we also omit many of the other control variables, we still find the same positive and negative significant effects of the proportions of the age groups when these control variables are omitted 
as the corresponding effects in the tables (at the 5 per cent level). There are some exceptions: If we either omit the log of the number of employees as control variable or do not control for year dummies, then several of the effects of the proportions of the age groups in the WRT sector will be significant (1 per cent level). We also find that the effect of the proportion of the youngest age group is negative and significant in the manufacturing sector if we omit the log of the number of employees as control variable ( 5 per cent level). These results show that the estimated effects of the age groups on the productivity-wage gap are not very sensitive to the inclusion of employee characteristics as gender and educational level, nor are these effects very sensitive to the inclusion of many of the firm characteristics as control variables.

\subsection{The Effects of the Other Explanatory Variables}

Tables 2, 3, 4 show that the log of the capital stock per employee has a positive effect on the productivity level and a negative effect on the productivity-wage gap in all regressions in each sector, except that there is a positive effect on the gap in the PST sector. Thus, a firm with a high capital stock per employee has a higher productivity level and (in most cases) a lower gap between the productivity level and the wage level than a less capital-intensive (measured per employee) firm.

In the manufacturing and WRT sectors, the number of employees in each firm has a positive effect on the productivity level, the wage level and the productivity-wage gap in the OLS regression, but a negative effect in the FE and GMM regressions. The productivity level and the wage level are positively affected and the gap is negatively affected by the number of employees in each firm in the OLS regression in the PST sector, while all three dependent variables are negatively affected by the number of employees in the FE and GMM regressions in this sector. These results are interesting as the average number of employees in each firm is much higher in the manufacturing sector than in the two service sectors, and about the same in the service sectors.

Using the estimates of the coefficients and standard errors of the number of employees in each firm, the estimate of the parameter $d^{Y}=p^{Y}+q^{Y}$ is found to be significantly different from one in all regressions in each sector (at the 1 per cent level). Therefore, we reject the hypothesis that the production function for each of the sectors has constant returns to scale with respect to capital and labour.

We find from the tables that the proportion of females of total employees has a negative effect on the productivity level in all regressions in each sector. The wage level is negatively affected by this proportion in the manufacturing and PST sectors. In the WRT sector, the proportion has a positive effect on the wage level in the OLS and FE regressions, but a non-significant effect in the GMM regression (at the 5 per cent level). The effect of the proportion of females has a negative effect on the productivity-wage gap in the OLS regression in each sector. The gap is only significantly affected by this proportion in the FE regression in the WRT sector and the GMM regression in the manufacturing sector, and both effects are negative. The proportion of employees with unknown gender has not a significant effect in the 
OLS and FE regressions in any of the sectors (this variable is omitted in the GMM regressions in each sector).

The estimated effects of the proportion of females on the dependent variables in the three sectors are interesting since the proportion of females varies considerably between the sectors. One possible explanation for the effects of this proportion can be that males and females work in different positions within firms. Unfortunately, we cannot control for such potential gender differences in the estimations, since we have no information about a worker's occupation in the combined data (see Sect. 7.1).

The estimated effects of the proportions of employees at different educational levels show that the estimates are highly sensitive with respect to sector and type of regression technique. Based on the GMM regressions, the proportion of employees with lower secondary education or less has a negative effect on the wage level in each sector. This proportion has a positive effect on the productivity-wage gap in the manufacturing and PST sectors, but a non-significant effect in the WRT sector. The proportion has only a significant effect on the productivity level in the manufacturing and WRT sectors, and both effects are negative.

Finally, the GMM regressions show that the proportion of employees with higher education has a negative effect on the productivity level and the wage level in the manufacturing and WRT sectors, and a positive effect on these levels in the PST sector. There is a non-significant effect of the proportion of those with higher education on the productivity-wage gap in each sector ( 5 per cent level). The proportion of employees with unknown or no completed education has only a significant effect on the gap in the WRT sector, and this effect is negative.

\section{Concluding Remarks}

We focus on how a firm's productivity level, wage level and productivity-wage gap are related to the age composition of its employees. The analysis is based on panel data of Norwegian firms in the following three sectors: the manufacturing sector, the sector of wholesale and retail trade, repair of motor vehicles and motorcycles ('the WRT sector'), and the sector of professional, scientific and technical activities ('the PST sector'). Three regression techniques are used: OLS, FE regression, and GMM regression in first differences. The following presentation of the results is based on the GMM regressions.

The estimation results show that a firm's productivity level is negatively affected by the proportion of the youngest age group, where the proportion of employees in the 40-49 age group is used as the reference category. These results hold for each of the three sectors, and are to some extent in line with the descriptive statistics. This indicates that workers between 40 and 49 years have a higher average individual productivity level than the youngest workers. The proportion of the 30-39 age group has a negative effect on the productivity level in the two service sectors, and the proportion of the oldest workers has a negative effect on this level in the WRT sector.

We find that the proportions of the two youngest age groups have a negative effect on the wage level in the WRT and PST sectors. In the WRT sector, this level is also negatively affected by the proportion of the oldest age group. The wage level in the 
manufacturing sector is only significantly affected by the proportion of the youngest workers, and the effect is negative. The estimated results of the wage level are to some extent in line with the descriptive statistics for the manufacturing and PST sectors, but to a small extent for the WRT sector.

The estimation results of the productivity-wage gap show that the proportion of the youngest employees has a positive effect on the gap in the PST sector, but a non-significant effect in the manufacturing and WRT sectors. The proportions of the other age groups than the youngest do not have a significant effect on the gap in any of the sectors. This indicates that there is no clear evidence of an age-related productivity-wage gap. The results of the productivity-wage gap are to some extent in line with the descriptive statistics for the manufacturing and PST sectors, but to a small extent for the WRT sector.

We have conducted a sensitively analysis for each sector in order to examine whether the estimated effects of the proportions of the different age groups on the productivity-wage gap are sensitive to the inclusion of different control variables. The results from this sensitivity analysis show that the estimated effects of the age groups on the gap are not very sensitive to the inclusion of employee characteristics as gender and educational level, nor are these effects very sensitive to the inclusion of many of the firm characteristics as control variables.

Furthermore, the descriptive statistics show that there is an overrepresentation of small firms in the full sample compared with the subsamples in each sector. This applies in particular to the manufacturing sector. As a result of this, we have conducted a sensitively analysis for each sector in order to examine whether the estimated effects of the proportions of employees in the different age groups are sensitive to this overrepresentation. The sensitivity analysis indicates that the effects of the proportions of the age groups in each sector are to a small extent sensitive to the overrepresentation of small firms.

Finally, the estimation results do not only indicate that workers in the 40-49 age group have a higher average individual productivity level than the youngest workers in each sector, but also indicate that this average level is higher among workers in their $40 \mathrm{~s}$ than among the oldest workers in the WRT sector. This points to a possible focus area for individual firms and policy makers: firms should involve more groups of employees, especially older employees since fewer training opportunities are offered to older workers than to younger ones (Skirbekk, 2004, p. 136). As concluded in Skirbekk (2004), on-the-job-training can increase the individual productivity level, but only up until a point where additional experience no longer improves this level. He also emphasises that the amount of training offered to older individuals could increase if the retirement age increases. The reason is that this would raise a firm's expected pay-off from human capital investments.

There are at least two limitations to this study. The first limitation is that we have measured the productivity level by the log of the turnover per employee. Cardoso et al. (2011) measure productivity as total sales per labour unit, but claim that total output (or valued added) would be a more accurate measure of productivity. This indicates that the use of turnover instead of total production as an indicator of productivity can be a limitation in our analysis. The choice of turnover for the computation of productivity is due to data availability. 
The second limitation is that the combined data do not allow to compute the proportions of workers by age in full-time equivalents. If the incidence of part-time work varies across age groups and over time within these groups, this may lead to biased results. According to Statistics Norway's LFS of employed persons in the period 2006-2016, the proportion of persons in full-time positions has varied between 73 and 74\% among all employed persons (15-74 years), between 42 and $48 \%$ among the 15-24 age group, between 78 and $81 \%$ among the 25-54 age group, and between 67 and $69 \%$ among the 55-74 age group. Thus, it seems that this proportion has not varied to a large extent over time. There have also been no large differences in the proportions between the 25-54 and 55-74 age groups. However, the proportion is significantly lower among the 15-24 age group compared with all employed persons. Unfortunately, the LFS data does not allow for splitting the 25-54 age group into finer age groups.

Acknowledgements I thank two anonymous referees for helpful and constructive comments on earlier versions of this article. All remaining errors are my own responsibility.

Open Access This article is licensed under a Creative Commons Attribution 4.0 International License, which permits use, sharing, adaptation, distribution and reproduction in any medium or format, as long as you give appropriate credit to the original author(s) and the source, provide a link to the Creative Commons licence, and indicate if changes were made. The images or other third party material in this article are included in the article's Creative Commons licence, unless indicated otherwise in a credit line to the material. If material is not included in the article's Creative Commons licence and your intended use is not permitted by statutory regulation or exceeds the permitted use, you will need to obtain permission directly from the copyright holder. To view a copy of this licence, visit http://creativecommons.org/licen ses/by/4.0/.

\section{References}

Aiyar, S., Ebeke, C., and Shao, X. (2016), The Impact of Workforce Aging on European Productivity, IMF Working Paper 16/238.

Aubert, P., \& Crépon, B. (2006). Age, wage and productivity: Firm-level evidence. A French version of this study has been published in Économie et Statistique, 368(2003), 95-119.

Barthel, J. (2008), Can age discrimination be justified with a lower productivity of older workers?, MPRA Paper No. 14682.

Bryson, A., Forth, J., Gray, H., \& Stokes, L. (2020). Does employing older workers affect workplace performance? Industrial Relations, 59(4), 532-562.

Børing, P. (2014). The impact of manufacturing firms' use of academic workers on their productivity level. Bulletin of Economic Research, 66(2), 156-172.

Børing, P., \& Grøgaard, J. B. (2021). Do older employees have a lower individual productivity potential than younger employees? Journal of Population Ageing. https://doi.org/10.1007/ s12062-020-09323-1

Börsch-Supan, A., \& Weiss, M. (2016). Productivity and age: Evidence from work teams at the assembly line. The Journal of the Economics of Ageing, 7, 30-42.

Cardoso, A. R., Guimarães, P., \& Varejão, J. (2011). Are older workers worthy of their pay? An empirical investigation of age-productivity and age-wage nexuses. De Economist, 159(2), 95-111.

Carlsson, M., \& Eriksson, S. (2019). Age discrimination in hiring decisions: Evidence from a field experiment in the labor market. Labour Economics, 59, 173-183.

Cataldi, A., Kampelmann, S., \& Rycx, F. (2012). 'Does it pay to be productive? The Case of Age Groups', International Journal of Manpower, 33, 264-283. 
de Hek, P., \& van Vuuren, D. (2011). Are older workers overpaid? A literature review. International Tax and Public Finance, 18(4), 436-460.

Dostie, B. (2011). Wages, productivity and aging. De Economist, 159(2), 139-158.

Göbel, C., \& Zwick, T. (2012). Age and productivity: sector differences. De Economist, 160, 35-57.

Hellerstein, J., \& Neumark, D. (2007). Production function and wage equation estimation with heterogeneous labor: Evidence from a new matched employer-employee data set. In E. R. Berndt \& C. R. Hulten (Eds.), Hard-to-measure goods and services: Essays in honor of Zvi Griliches (pp. 31-71). Chicago: University of Chicago Press.

Henkens, K., \& van Dalen, H. P. (2013). The employer's perspective on retirement. In M. Wang (Ed.), The Oxford Handbook of Retirement (pp. 215-228). Oxford University Press.

Krugman, P. R. (1997), The age of diminished expectations: U.S. Economic Policy in the 1990s, third edition, London: The MIT Press.

Lallemand, T., \& Rycx, F. (2009). Are older workers harmful for firm productivity? De Economist, 157, 273-292.

Lazear, E. P. (1979). Why is there mandatory retirement? Journal of Political Economy, 87, 1261-1284.

Loewenstein, G., \& Sicherman, N. (1991). Do workers prefer increasing wage profiles? Journal of Labor Economics, 9(1), 67-84.

Neumark, D. (2020), Age discrimination in hiring: Evidence from age-blind vs. non-age-blind hiring procedures, NBER Working Paper 26623.

OECD (2013), Ageing and employment policies: Norway 2013: Working better with age, OECD Publishing.

OECD (2016), Skills matter: Further results from the survey of adult skills, OECD skills studies, OECD Publishing, Paris

OECD (2019), OECD Compendium of Productivity Indicators 2019, OECD Publishing, Paris.

OECD (2020), OECD employment outlook 2020: worker security and the COVID-19 crisis, OECD Publishing, Paris.

Scarth, W. (2002). Population Aging, Productivity and Living Standards. In A. Sharpe, F. St-Hilaire, \& K. Banting (Eds.), The review of economic performance and social progress 2002: towards a social understanding of productivity (pp. 145-156). Centre for the Study of Living Standards, The Institute for Research on Public Policy (IRPP), Montreal.

Skirbekk, V. (2004). Age and individual productivity: A literature survey. Vienna Yearbook of Population Research, 2, 133-154.

Skirbekk, V. (2008). Age and productivity potential: A new approach based on ability levels and industrywide task demand. In A. Prskawetz, D. E. Bloom, \& W. Lutz (Eds.), Population Aging, Human Capital Accumulation, and Productivity Growth (pp. 191-207). Population Council.

Solem, P. E. (2012). Possible effects of the financial crisis on managers' attitudes to older workers. Nordic Journal of Working Life Studies, 2, 129-142.

Töpfer, M. (2020). The age pay gap and labour market heterogeneity: A new empirical approach using data for Italy. Labour, 34(1), 1-25.

Tracy, J. S. (1986), Seniority rules and the gains from union organization, NBER Working Paper 2039.

Van Dalen, H. P., Henkens, K., \& Schippers, J. (2010). Productivity of older workers: perceptions of employers and employees. Population and Development Review, 36, 309-330.

van den Berg, A., \& Groot, W. (1992). Union membership in the Netherlands: A cross-sectional analysis. Empirical Economics, 17(4), 537-564.

Van Ours, J. C. (2009). Will you still need me: When I'm 64? De Economist, 157, 441-460.

Van Ours, J. C., and Stoeldraijer, L. (2011), 'Age, wage and productivity in dutch manufacturing', De Economist, 159, 113-137.

Publisher's Note Springer Nature remains neutral with regard to jurisdictional claims in published maps and institutional affiliations. 